\title{
Can Jurisdictional Uncertainty and Capital Controls Explain the High Level of Real Interest Rates in Brazil? Evidence from Panel Data*
}

\author{
Fernando M. Gonçalves ${ }^{\dagger}$, Márcio Holland ${ }^{\ddagger}$, Andrei D. Spacov ${ }^{\S}$
}

Contents: 1. The Short-term Real Interest Rate in Brazil: Why So High?; 2. The Concept of Jurisdictional Uncertainty: A Closer Look; 3. The Data; 4. Testing ABL's Conjecture and Its Variants; 5. Conclusions; A. Appendix.

Keywords: Real Interest Rates; Jurisdictional Uncertainty; Institutions; Credit Markets; Capital Controls; Currency Convertibility.

JEL Code: E43; E50; F41; K40.

Esse paper testa a hipütese, popularizada por Arida et al. (2005), de que riscos associados à incerteza jurisdicional e incoversibilidade da moeda nacional são importantes determinantes dos altos níveis da taxa básica de juros no Brasil. Os resultados dos testes são bastante desfavoráveis não apenas a essa hipotese, mas também a variantes dela. Os resultados também indicam que fatores tradicionais fiscais e monetários são bem mais relevantes para explicar o nível da taxa básica de juros, em comparação ao par incerteza jurisdicional/incoversibilidade da moeda.

This paper tests the assertion, popularized by Arida et al. (2005), that risks associated with the jurisdiction and currency inconvertibility are relevant determinants of the high level of short-term real interest rates in Brazil. The results are by and large unfavorable not only to their conjecture, but also to variants of their argument. The results further indicate that traditional monetary and fiscal factors are far more relevant to explain the level of short-term real interest rates than the binomial jurisdictional uncertainty/currency inconvertibility is.

\footnotetext{
* The authors would like to thank Barry Eichengreen, Edmar Bacha, Maurice Obstfeld and Marcelo Portugal for very helpful comments and Timothy Callen for providing data on public debt stocks in various emerging market economies.

$\dagger$ Department of Economics, University of California at Berkeley, Berkeley, CA, USA. E-mail: fgoncalves@imf . org.

¥São Paulo School of Economics, EESP-FGV-SP and CNPq Researcher. E-mail: marcio.holland@f gv.br.

$\S$ Department of Economics, University of California at Berkeley, Berkeley, CA, USA. E-mail: spacov@econ. berkeley .edu. Bolsista do Governo Brasileiro - CAPES - Brasil.
} 


\section{THE SHORTTERM REAL INTEREST RATE IN BRAZIL: WHY SO HIGH?}

1

Explaining the high level of the real interest rate in Brazil in recent years has become a challenge for Brazilian economists and foreign observers alike. After the implementation of the Real Plan in July 1994, which stabilized the value of the currency after many years of high inflation, real interest rates have been at extremely high levels in comparison to most countries in the world. As Figure 1 shows, Brazilian short-term real interest rates averaged more than 14\% per year over the period 1996-2002, a level significantly higher than in developed economies and also substantially above the basic rates observed in similar developing economies.

Figure 1 - Selected Countries: Real Interest Rate (Average 1996-2002)

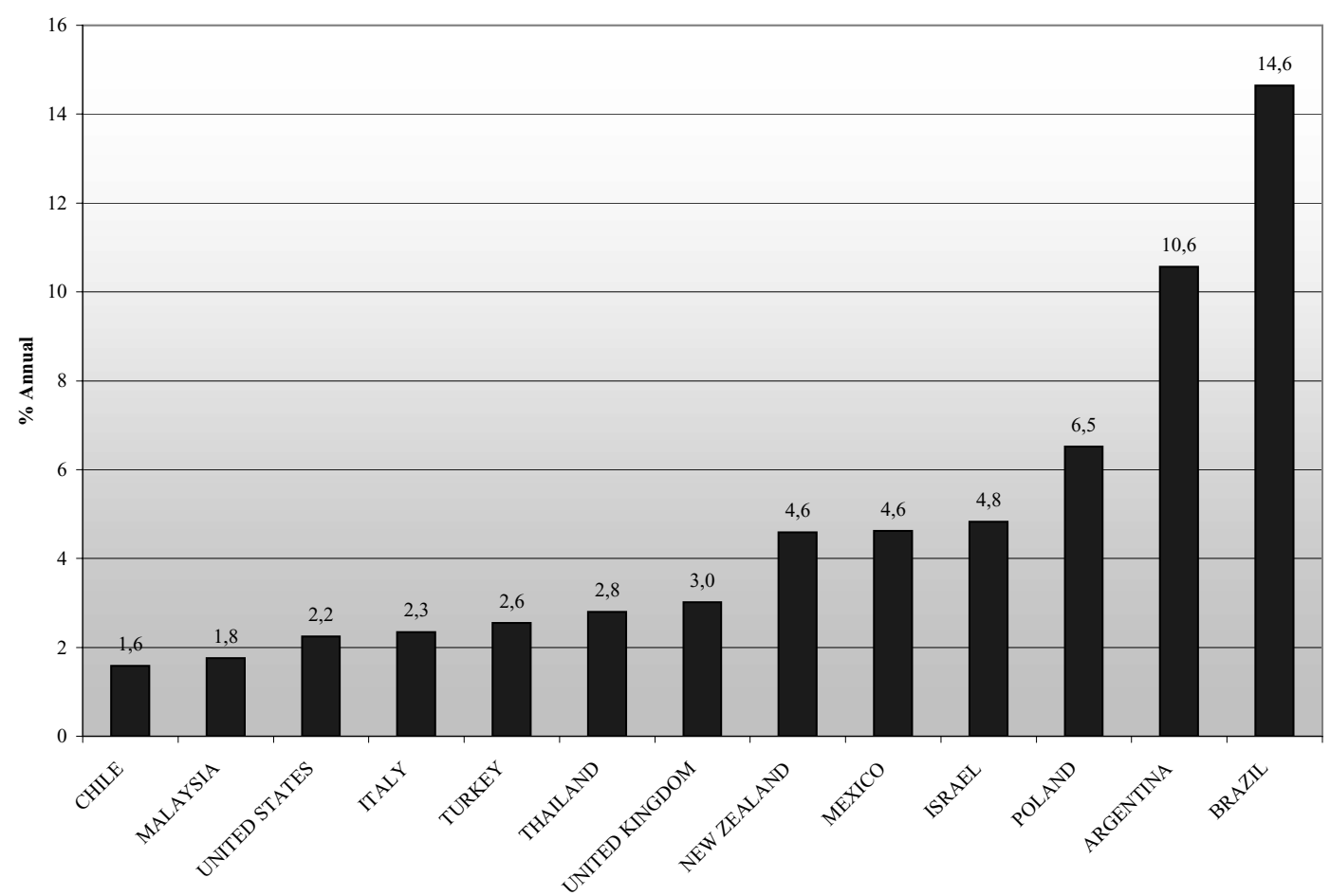

Source: IMF's IFS

From July 1994 until the beginning of 1999, there were some important macroeconomic imbalances that could reasonably explain the high real interest rates observed in Brazil. In particular, the lax fiscal policy during this period, which produced no primary surpluses to reduce the already high public debt levels, coupled with a pegged and overvalued exchange rate, were considered by many observers to be at the root of the problem. At that time, monetary policy was mainly oriented to preserve the value of the currency relative to the dollar and, consequently, real interest rates had to be kept high as long as the exchange rate was kept overvalued. Consistent with this view, Figure 2 shows that, as

${ }^{1}$ For simplicity, throughout the paper we will often refer to the short-term real interest rates simply as "real interest rates" or just "interest rates". 
such imbalances were becoming more and more evident to foreign investors, increasingly higher real interest rates were necessary to sustain the overvalued currency in Brazil.

Figure 2 - Real Interest Rate: Selected Countries (Annual Percentage 1996-2002)

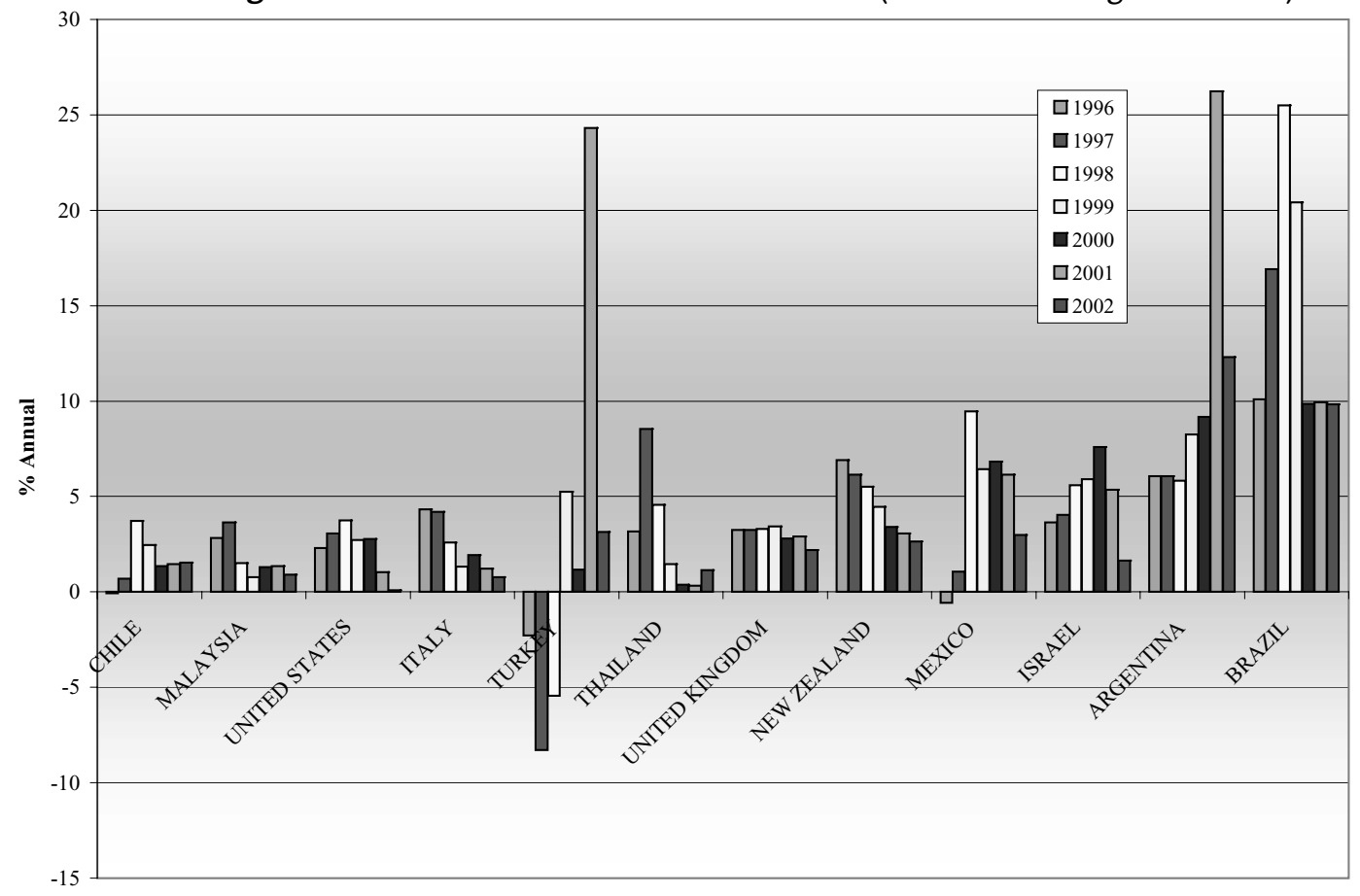

Source: IMF's IFS

In February 1999 the exchange rate was allowed to float and in June of the same year the Central Bank adopted a formal inflation targeting regime framework. As predicted, real interest rates dropped to levels on average lower than before. However, as the graph above shows, real interest rates in Brazil after the currency devaluation of 1999 remained close to $10 \%$ per year, a still very high level in comparison to other emerging market economies. ${ }^{2}$

Initially, it was thought that the persistence of such high real interest rates in a flexible exchange rate environment was due to the still high current account deficits that the country was running. The basic argument was that this tended to cause sharp currency volatility which, in turn, fed into a vigorous inflation pass-through. However, even with a strong shift in the current account balance taking place in the last four years (in fact, to a small surplus), Brazil still seems to be trapped under the high real interest rate problem.

Moreover, not even the sharp downward path of interest rates that took place recently in the leading economies, creating an unprecedented benefic liquidity environment, enabled the country to bring local real interest rates below the $10 \%$ per year threshold. Note in Figure 2 that, except from the cases of

\footnotetext{
${ }^{2}$ According to our calculations (also based on IFS data) the real interest rate for 2003 and 2004 in Brazil (not depicted in the graph above) were roughly $7 \%$ and $9.2 \%$ respectively. Hence, despite being at lower levels in the last two years than in the period from 1999 to 2002, real interest rates remained very high in Brazil in most recent years as well.
} 
Brazil and Argentina, most other countries show a visible decline in real interest rates in the past few years, following the trend of the US and other leading economies.

Looking from a strict 'inflation targeting' standpoint ${ }^{3}$, the problem clearly cannot be blamed on excess conservatism by Brazilian central bankers. As the chart below shows, such high real interest rates have not prevented consumer inflation in Brazil from growing substantially above targets recently. Compared to other developing economies, Brazilian inflation has been much more resilient despite the fact that real interest rates in Brazil are much higher.

Figure 3 - Inflation Rate: Brazil and Regions (Annual Percentage 1995-2003)

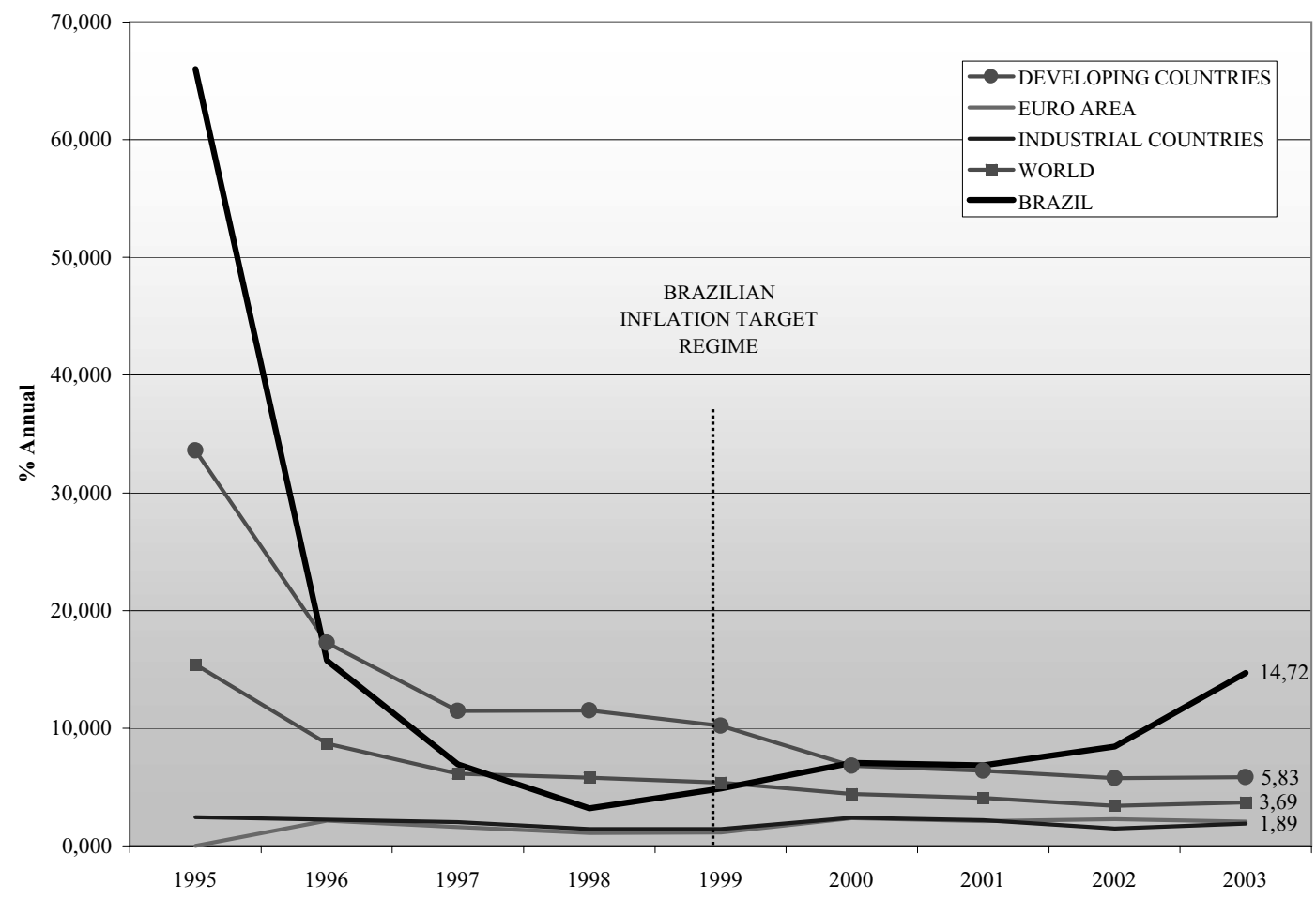

Source: IMF's IFS

Why did real interest rates in Brazil remain high after the floating of the Real in 1999? Why are real interest rates in Brazil still so high today? As years have passed since the realignment of the currency and the implementation of inflation targeting and floating exchange rates in 1999, the search for alternative explanations to the phenomenon of high real interest rates in Brazil has generated a vast literature that points to various plausible explanations.

Garcia (2004) notes that two international liquidity crises hit the Brazilian economy in 2001 and 2002, causing a reversal of capital flows, a reduction of economic activity, and leading to higher inflation and interest rates. In an effort to explain these events, the author relies on a model by Caballero and Krishnamurthy (2002) in which domestic and international financial markets are segmented and international liquidity is needed for local investment. In such model, a negative shock in international

\footnotetext{
${ }^{3}$ See Kanczuk (2002) and Bonomo and Brito (2002) for interesting technical discussions on monetary policy models for Brazil.
} 
liquidity constrains local investment and leads the Central Bank to raise interest rates to alleviate the exchange rate depreciation. Although the model adequately describes the events experienced by the Brazilian economy during the liquidity crises of 2001 and 2002, it does not satisfactorily explains why interest rates remained high as those liquidity problems faded away. The experience of the years 2000 and more recently 2003 and 2004, showed that the country failed to bring real interest rates below the $10 \%$ threshold even in an environment of low sovereign spreads and abundant international liquidity fostered by record low interest rate levels in the US and most of the developed world.

Similar to Garcia (2004), other analysts emphasize the impact that various adverse shocks experienced by the Brazilian economy might have had in the real interest rate. ${ }^{4}$ Shocks commonly cited by this strand of the literature include, among others, the blow up of the Nasdaq bubble, the September 11 terrorist attacks, the collapse of Argentina's currency board regime, the domestic energy crisis, and the economic uncertainty generated by the Presidential election of 2002 in Brazil. Like the liquidity crises emphasized by Garcia (2004), all these shocks can explain spikes in the real interest rate, but it is not clear how they can elucidate the fact that real interest rates in Brazil have stayed at persistently high levels during all this period.

Another strand of the literature emphasizes the huge burden that Brazil's public debt services place at the government's budget. Favero and Giavazzi (2002) decompose the difference between the shortterm interest rate (the Selic rate) and interest rates at longer maturities in Brazil into the relative contributions of monetary policy and the term premium. They find that the difference is mainly determined by the term premium, not by expectations of future monetary policy. Because the term premium is strongly correlated with Brady bonds spreads, which are not directly affected by devaluation expectations, the authors conclude that macroeconomic fundamentals and debt dynamics must be the main determinants of the term premium. According to this view, the real interest rates will remain high as long as the debt problem is not properly addressed. The authors then show that primary surpluses in Brazil have not been enough to stabilize the debt-to-GDP ratio and argue that the fiscal effort should be increased. They also discuss various strategies that could be adopted in Brazil to improve debt management in order to equilibrate the fiscal stance. ${ }^{5}$.

Arida et al. (2005) (henceforth, ABL) provide a third explanation for the high real interest rates in Brazil. The authors argue that, in order to explain their persistently high levels, a distortion of a resilient nature has to exist. They identify a form of risk, not previously discussed by the literature, which is related to the uncertainties in the settlement of contracts within the Brazilian jurisdiction. According to the authors, the risk associated with the Brazilian jurisdiction, which they label "jurisdictional uncertainty", is the underlying reason for having persistently high interest rates in Brazil. To provide evidence in support of their conjecture, the authors point to the fact that, while there is a large longterm credit market to Brazilian debtors abroad, there is no domestic long-term bond and credit markets in Brazil. According to them, this signals the existence of a risk factor associated with the Brazilian jurisdiction. ${ }^{6}$

\footnotetext{
${ }^{4}$ Salgado et al. (2005) use a Threshold Autoregressive model to explain a change in regime in Brazilian nominal interest rates. The authors estimate the Central Bank's reaction function after Brazil launched the Real Plan, in July 1994. Their empirical findings suggest that a linear model for this reaction function shows signs of misspecification, especially due to the large residuals in periods associated with crises.

${ }^{5}$ Other recent papers stress the interaction between fiscal and monetary policy in Brazil. Hillbrecht (2001) evaluates a framework where fiscal and monetary authorities interact strategically in a non-cooperative game and the results suggest that the policy designed to reduce monetary authority inflation bias can reduce society's welfare. Rocha and Picchetti (2005) address important questions about the current fiscal adjustment strategy and they conclude that there is a low chance of it being successful.

${ }^{6}$ It should be noted that the long-term debt Brazil issued abroad is fully denominated in foreign currency (dollars). However, the authors argue that the currency denomination of contracts cannot explain the inexistence of local long-term credit markets since not even the Brazilian Treasury is able to issue long-term dollar-linked bonds domestically. This view contrasts strikingly with the literature on "Original Sin", inaugurated by Eichengreen and Hausmann (1999), according to which the incompleteness of international capital markets is what prevents countries from issuing debt abroad in local currency (see Eichengreen et al.
} 
But a bad jurisdiction is clearly not enough to explain why real interest rates in Brazil are so much higher than in other developing countries, many of which have equally bad or even worse jurisdictions. Recognizing this problem, the authors argue that what makes Brazil's real interest rates especially high within the developing countries group is the relative inconvertibility of its currency in association with the jurisdictional problem. Arida $(2003 \mathrm{~b}$,a) develops the currency inconvertibility argument more extensively, claiming that even though there has been a considerable liberalization of the capital account in Brazil in the nineties, the remaining capital controls still in place impose unnecessary pressure on the country risk premium, with adverse consequences for the local interest rate as well. He argues that a more convertible currency would significantly lower sovereign spreads through the elimination of its "currency conversion" component, giving room for a consistent reduction in the local real interest rate?

It will be our main purpose in this paper to test the conjectures presented by ABL. We use two different panel datasets to investigate whether jurisdictional uncertainty and the degree of currency inconvertibility can explain the observed cross-country differences in short-term real interest rate levels. The datasets differ in that they include different jurisdictional uncertainty measures and cover different, although partially overlapping, periods. The panel structure of the datasets will be particularly useful to control for country-specific effects not explicitly included as explanatory variables in the regression.

The remainder of the paper is divided as follows. Section 2 thoroughly discusses the concept of jurisdictional uncertainty. Section 3 discusses advantages and shortcomings of each of the measures of jurisdictional uncertainty and currency inconvertibility that will be used in our empirical exercise. It also briefly discusses the fiscal and monetary policy control variables we use in our regressions. The empirical methodology and analysis of the data are presented in Section 4. Section 5 presents our conclusions.

\section{THE CONCEPT OF JURISDICTIONAL UNCERTAINTY: A CLOSER LOOK}

The purpose of this section is twofold. First, we review the concept of jurisdictional uncertainty developed by ABL aiming at establishing a clear definition of it. Second, we discuss the possible connections between jurisdictional uncertainty, currency inconvertibility and the short-term real interest rate.

\subsection{Defining Jurisdictional Uncertainty}

The concept of jurisdictional uncertainty developed by ABL can be defined as an anti-saver and anticreditor bias, which manifests itself as "the risk of acts of the Prince changing the value of contracts before or at the moment of their execution, and as the risk of an unfavorable interpretation of the contracts in case of a court ruling." 8

Hence, the presence of jurisdictional uncertainty is directly related to the existence of institutions that are permissive to the bias against creditors and savers. The authors recognize the link between jurisdictional uncertainty and the quality of institutions in the following excerpt: ${ }^{9}$

The concept of jurisdictional uncertainty conforms to the growing consensus among economists and political scientists that the social, economic, legal and political organizations of a society, i.e., its "institutions" are a primary determinant of its economic performance (North,

(2004)).

${ }^{7}$ This view is criticized by Belluzzo and Carneiro (2004) and Oreiro et al. (2004), which argue instead that capital controls should be raised in order to eliminate the possibilities of arbitrage between foreign and domestic interest rates, what would allow for the immediate reduction of the later.

${ }^{8}$ See Arida et al. (2005). No emphasis in the original.

${ }^{9}$ See Arida et al. (2005). 
1981). Overcoming jurisdictional uncertainty involves recasting private contracts' supporting institutions - that Acemoglu and Johnson (2005) call "contractual institutions" - and those that impede the expropriation by the government or the elites - "political institutions" or "property right institutions", in the terminology of those authors.

This link between institutions and jurisdictional uncertainty will be important for our empirical investigation. Indeed, as will be seen below, in our empirical exercise we proxy jurisdictional uncertainty by institutional variables with the goal of capturing the anti-saver/anti-creditor bias of a country.

\subsection{The Impact of a Bad Jurisdiction in the Economy}

ABL point to two important effects a bad jurisdiction might have in the economy. First, a bad jurisdiction can be the underlying cause of the inexistence of local long-term bonds and credit markets. The resistance of individuals and firms to make their domestic savings available for the long run might be a direct consequence of the anti-saver bias present in countries that have a bad jurisdiction. Similarly, in countries where an anti-creditor bias is pervasive, creditors will not be willing to lend domestically. ${ }^{10}$

Important as the connection between jurisdictional uncertainty and credit is, we will not emphasize it in the present paper, since the topic would deserve a paper entirely dedicated to it. Instead, we will thoroughly investigate another potential outcome of a bad jurisdiction suggested by ABL: a persistently high level of the short-term real interest rate. As we saw before, explaining why the short-term real interest rate is persistently high is particularly important in Brazil, a country in which the average basic real interest rate over the period 1996-2002 has been considerably above other developing countries'.

As ABL note, what calls attention in the Brazilian case comparatively to other emerging market economies is the strong impact of jurisdictional uncertainty on short-term real interest rates. They explain the large effect that jurisdictional uncertainty has in Brazil by calling attention to another important feature of the Brazilian economy: the currency is relatively less convertible there when compared to other emerging market economies. They argue that, besides the quality of the jurisdiction, the degree of currency inconvertibility is also a fundamental determinant of the level of short-term real interest rates.

To back their view, ABL provide a simple model that generates the prediction that both jurisdictional uncertainty and currency inconvertibility are positively related to the short-term interest rate. In the model, a decline in jurisdictional uncertainty reduces the short-term interest rate required to keep inflation at a given level. The mechanism works via the real exchange rate and follows a similar model used by Blanchard (2004). Basically, a decrease in jurisdictional uncertainty increases the expected return on short-term investment in domestic assets, which causes an incipient capital inflow and the real appreciation of the currency at the short-term interest rate set by the Central Bank. The appreciation of the currency then allows for a lower level of interest rates, as the Central Bank in their model is purely inflation-targeted.

But how do jurisdictional uncertainty and currency inconvertibility interact to create the various levels of short-term interest rates observed across countries? Although their model is not designed to answer this question, $A B L$ describe their view about the issue by analyzing four representative situations, providing real examples to each of them. Specifically, they briefly discuss the combination of the following benchmark cases: good versus bad jurisdiction, and convertible versus inconvertible currency. The following table summarizes their conjecture:

As the table shows, if the jurisdiction is good, ABL predict that the short-term interest rate will be low, independently of the degree of inconvertibility of the currency. In this sense, they attribute a primordial role for the quality of the jurisdiction as a determinant of the short-term real interest rates.

\footnotetext{
${ }^{10}$ See Pinheiro and Cabral (2001) for an early empirical study of the impact of judicial enforcement on the development of credit markets in Brazil.
} 
Table 1 - Benchmark Cases

\begin{tabular}{|l|l|l|}
\hline & Good Jurisdiction & Bad Jurisdiction \\
\hline Convertible Currency & $\begin{array}{l}\text { Low short-term real interest } \\
\text { rates (e.g. Mexico) }\end{array}$ & $\begin{array}{l}\text { Moderate short-term real inter- } \\
\text { est rates (e.g. Peru) }\end{array}$ \\
\hline Inconvertible Currency & $\begin{array}{l}\text { Low short-term real interest } \\
\text { rates (e.g. India) }\end{array}$ & $\begin{array}{l}\text { High short-term real interest } \\
\text { rates (e. g. Brazil) }\end{array}$ \\
\hline
\end{tabular}

In fact, their conjecture attributes a relevant role for the degree of currency inconvertibility only when the jurisdiction is bad. In particular, when the jurisdiction is bad but the currency is convertible we would observe a moderate level of short-term interest rates that is solely driven by the bad jurisdiction. In the case where the jurisdiction is bad and the currency inconvertible, the capital controls in place impose an even higher pressure on the country risk premium, culminating in high short-term interest rates as the ones observed in Brazil.

ABL's conjecture about the role of jurisdiction uncertainty and currency inconvertibility as determinants of the short-term real interest rate can be summarized with the aid of the graphs below.

Figure 4 - ABL's Conjecture
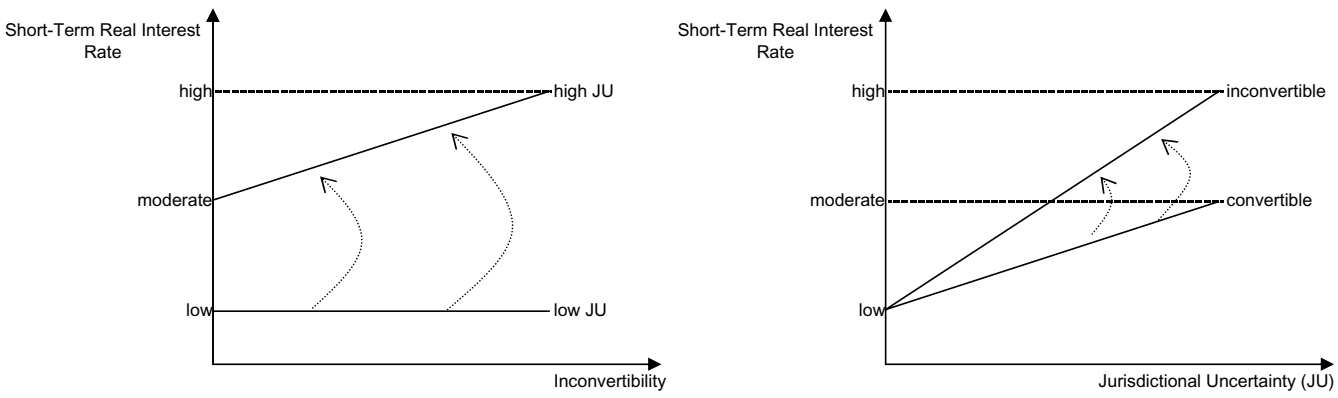

The graph in the left-hand side shows the short-term real interest rate as a function of the degree of inconvertibility of the currency for given levels of jurisdictional uncertainty. When jurisdictional uncertainty is low (good jurisdiction), the degree of currency inconvertibility is not relevant to determine the level of the short-term real interest rate. However, when jurisdictional uncertainty is high (bad jurisdiction), the degree of currency inconvertibility becomes an important determinant of the short-term real interest rate: the more inconvertible the currency is, the higher is the short-term real interest rate. The graph in the right-hand side, for its turn, shows how the level of the short-term real interest rate varies with jurisdictional uncertainty for given degrees of inconvertibility of the currency. The more inconvertible is the currency, the larger will be the impact of jurisdictional uncertainty on the short-term real interest rate.

The following functional form for the short-term real interest rate $\mathrm{r}$ can be used to produce the graphs above:

$$
r=\alpha+\beta \cdot J U+\gamma \cdot I N C O N V+\delta \cdot J U \cdot I N C O N V
$$

where $J U$ measures the degree of jurisdictional uncertainty, INCONV measures the degree of currency inconvertibility, and $\alpha, \beta, \gamma$ and $\delta$ are parameters. To see under what conditions this equa- 
tion is consistent with ABL's conjecture, we can simply take its first-order derivative with respect to $I N C O N V$ and with respect to $J U$ and compare the results with the slopes of the two graphs above. The first-order derivatives are:

$$
\frac{\partial r}{\partial I N C O N V}=\gamma+\delta \cdot J U
$$

and

$$
\frac{\partial r}{\partial J U}=\beta+\delta \cdot I N C O N V
$$

The derivative of $\mathrm{r}$ with respect to the degree of currency inconvertibility is consistent with the slopes of the lines in the graph in the left-hand side above if and only if $\gamma=0$ and $\delta>0$. Similarly, the derivative of $r$ with respect to jurisdictional uncertainty is consistent with the slopes of the lines in the right-hand side graph above if and only if $\beta>0$ and $\delta>0$. It is also easy to see that if the signs of the parameters are as described, the expression above for $r$ is not only consistent with the slopes of the lines but also with the levels depicted in the graph for the short term real interest rate.

In our empirical exercise we use these predictions to test ABL's conjecture by estimating an equation with the short-term real interest rate as the dependent variable and a measure of jurisdictional uncertainty and its corresponding interaction with an index of currency inconvertibility as explanatory variables. It should be noted, however, that while ABL might be right about the fact that jurisdictional uncertainty and the degree of inconvertibility of the currency are determinants of the short-term real interest rate level, they might be wrong about the way these two variables interact to create the various levels of short-term interest rates observed across countries. Hence, we also investigate if variants of ABL's conjecture are consistent with the data. In particular, we investigate the possibilities depicted in the graphs in the next page.

Variant 1 is a generalization of ABL's conjecture that allows the degree of inconvertibility of the currency to also have a direct impact on interest rate levels. The only difference to ABL's original conjecture is that, in this case, the degree of inconvertibility of the currency affects the level of short-term real interest rates even when the jurisdiction is good. It is easy to show that variant 1 will occur when $\beta>0, \gamma>0, \delta>0$.

Variant 2, on the other hand, assumes that both jurisdictional uncertainty and currency inconvertibility affect the level of short-term real interest rates, but only directly. This means that there is no interaction term and, in particular, the impact of jurisdictional uncertainty is not magnified by the degree of currency inconvertibility, as ABL originally assumed. Similarly, the effect of currency inconvertibility in the short-term real interest rate level would be independent of the quality of the jurisdiction. It is straightforward to show that the parameters in the equation for $\mathrm{r}$ above should satisfy the following conditions for variant 2 to hold: $\beta>0, \gamma>0$, and $\delta=0$.

Finally, variant 3 illustrates the case in which the degree of inconvertibility of the currency is the primordial determinant of the level of short-term real interest rates, while the quality of the jurisdiction only matters when the currency is highly inconvertible. Hence, jurisdictional uncertainty would only have a magnifying impact on real interest rates via its interaction with inconvertibility, but would have no direct impact per se. In this case, we would need to have the following conditions holding: $\beta=0$, $\gamma>0$, and $\delta>0$.

In the empirical part of the paper, we will test the validity of all these variants along with the validity of ABL's original conjecture. 
Figure 5 - Variants on ABL's Conjecture

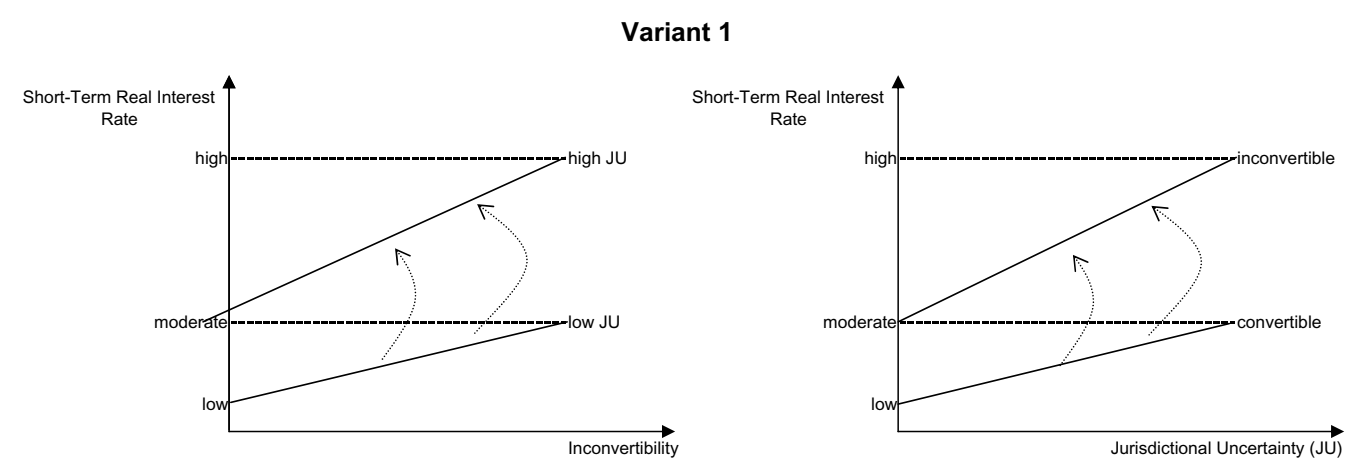

Variant 2
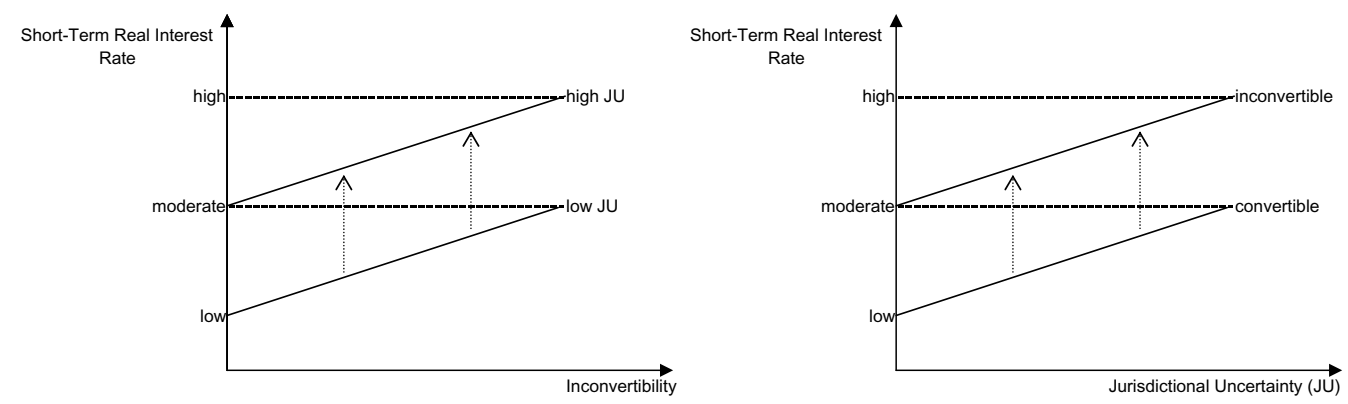

Variant 3
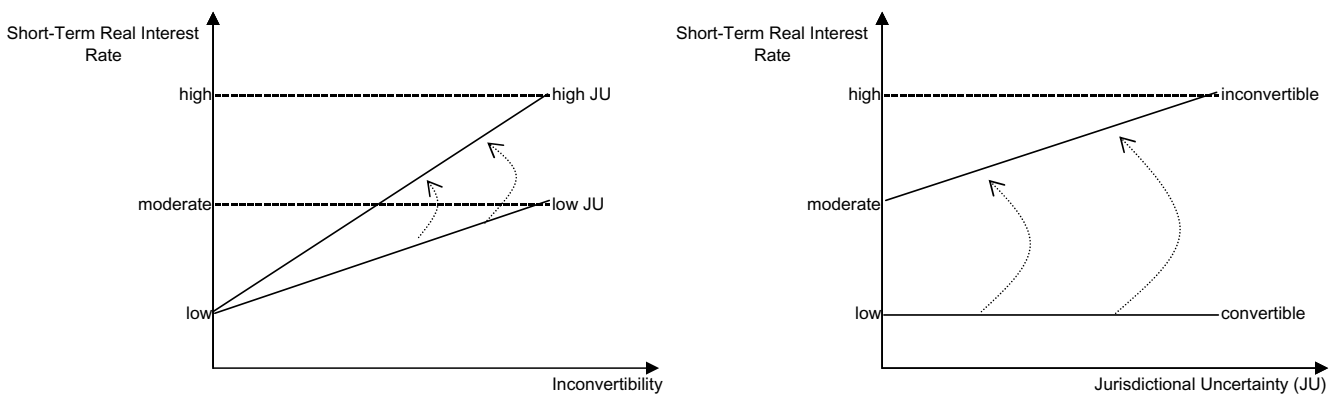


\section{THE DATA}

In this section we present the variables to be used in our empirical exercise and discuss their advantages and potential shortcomings. ${ }^{11}$

\subsection{Measuring Jurisdictional Uncertainty}

One of the main difficulties in testing the hypothesis posed by ABL comes from the fact that it is not easy to come up with a jurisdictional uncertainty measure that captures the exact nuances emphasized in their argument. In order to overcome this problem, our approach was to use the largest possible set of jurisdictional measures available from reliable sources. Even though within this set there is not a single ideal measure that precisely captures the definition of jurisdictional uncertainty suggested by $\mathrm{ABL}$, an empirical investigation based on a wider set of measures is likely to capture most of the effects of the anti-saver/anti-creditor bias described by ABL.

A second drawback that one realizes when searching for data on jurisdictional uncertainty is that the time series available for Brazil are relatively short, corresponding in general to a few observations on an annual frequency. This puts severe limitations on the use of any statistical technique based solely on time series analysis, automatically leading to a search for more observations on the cross-country dimension. In this sense, it may not be possible to completely understand the interactions between the degree of jurisdictional uncertainty and interest rates over time, but on the other hand one might learn a lot about the interaction of these two variables from the cross-country comparisons, as we chose to do in this study. ${ }^{12}$ Fortunately, there has been a growing interest on measuring the rule of law and other institutional aspects of countries in the past few years, and this has already produced comprehensive surveys on this subject, resulting in a wide data span covering most countries in the world.

The first set of jurisdictional uncertainty measures that we use draws from the work of Kaufmann et al. (2004) at the World Bank, covering 199 countries and territories for four different years: 1996, 1998, 2000 and 2002. These authors have compiled 25 separate data sources constructed by 18 different organizations ${ }^{13}$ and, using the statistical method of unobserved components, they constructed six aggregate governance indicators, two of which are of special interest for our purposes: Rule of Law and Regulatory Quality. ${ }^{14}$ According to the authors, Rule of Law aggregates indicators that "measure the extent to which agents have confidence in and abide by the rules of society. These include perceptions of the incidence of crime, the effectiveness and predictability of the judiciary and the enforcement of contracts". On the other hand, Regulatory Quality "includes measures of incidence of market-unfriendly policies such as price controls or inadequate bank supervision, as well as perceptions imposed by excessive regulation in areas such as foreign trade and business development" (Kaufmann et al., 2004).

Figures 6 and 7 illustrate the averages over time of the two measures of jurisdictional uncertainty in selected countries. ${ }^{15}$ It can be seen that Brazil shows weakness in its governance indicators even

\footnotetext{
${ }^{11}$ See the appendix for tables with the main features of each variable we use. Table 6 shows a general description, the scale, the sources and the periods of each variable. Tables 7 shows their averages over time for each country in our sample and also some basic statistics of the country-year observations of each variable.

12 Another reason not to rely solely on time-series analysis is that some measures of jurisdictional uncertainty might not vary much over time for a country (indeed, according to ABL, it is precisely the resilient nature of jurisdictional uncertainty that is potentially useful in explaining the persistence of high interest rate levels).

13 These include international organizations, political and business risk-rating agencies, think-tanks, and non-governmental organizations.

${ }^{14}$ The complete list is: Voice and Accountability, Political Stability and Absence of Violence, Government Effectiveness, Control of Corruption, Regulatory Quality and the Rule of Law.

${ }^{15}$ In the original institutional measures from the World Bank and the Fraser Institute higher values are assigned for better institutions. However, in order to capture the degree of jurisdictional uncertainty in each country, we inverted the scale so that larger scores represent worse institutions (and worse jurisdictions).
} 
in comparison with some other emerging market economies. However, when compared with figure 1 , countries with better rule of law and regulatory quality do not necessarily have a lower real interest rate. Brazil and Argentina grade low in its institutional measures and have high interest rates, but this negative correlation is not clear for the other countries. We leave for the empirical section of the paper a more formal analysis of this issue.

Figure 6 - Currency Inconvertibility Index: Selected Countries (Average 1996-2002)

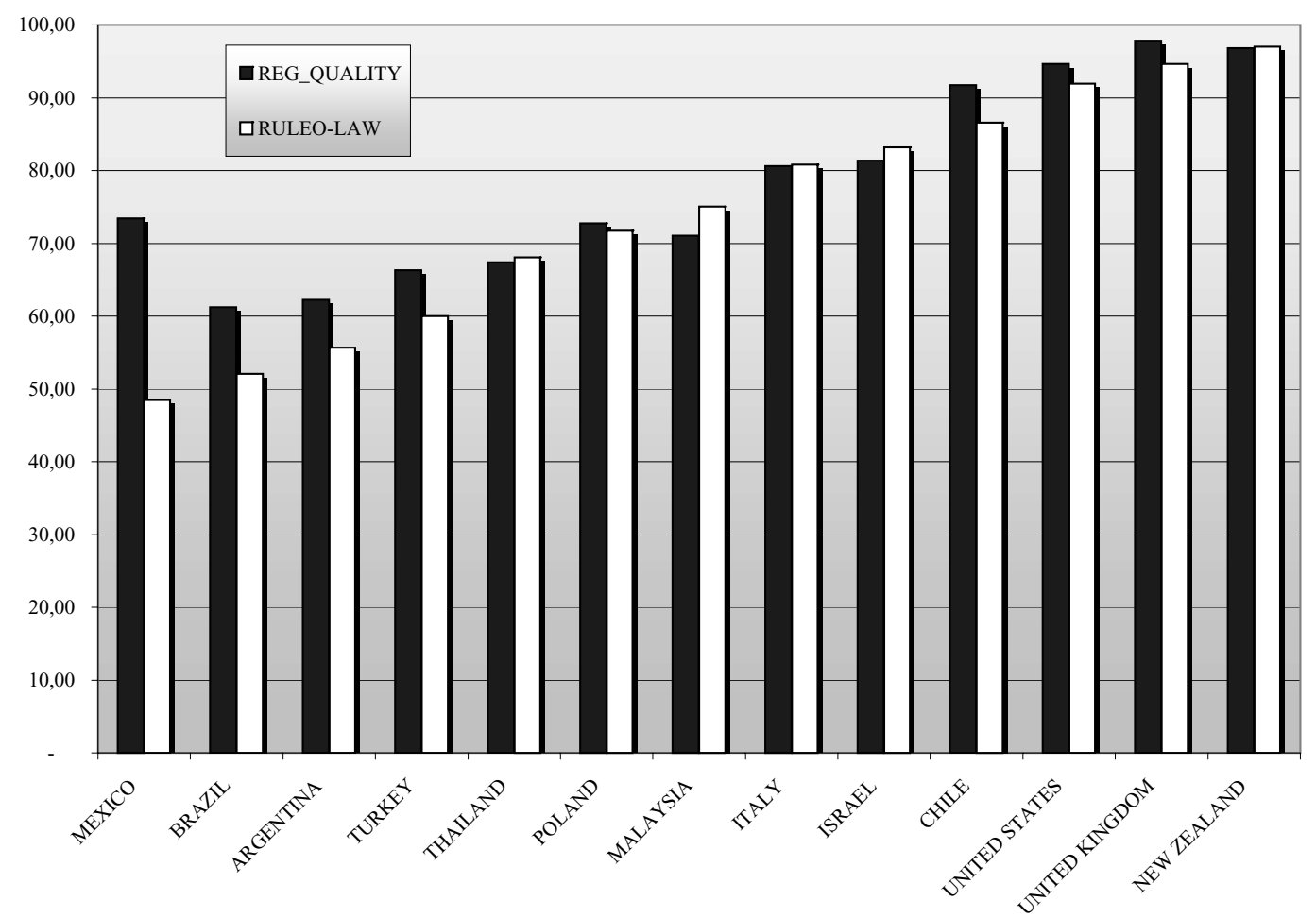

Source: World Bank, Kaufmann et al. (2004) and Author's calculations. Note: Minimum is 0 and maximum is 100 , with higher values for higher jurisdictional uncertainty.

The main drawback from using these two measures to capture jurisdictional uncertainty in the sense suggested by ABL is that, being aggregate measures constructed over other individual indicators, they tend to include some noise features that are not directly linked to credit markets, such as the "perceptions of incidence of crime" within Rule of Law for example. However, this database has several other desirable features that make it probably the most reliable source for capturing cross-country differences in institutions, as we argue below.

First of all, the World Bank governance indicators not only allow making comparisons among nearly all countries in the world, but they also do so for a panel of four different time periods. Given the scarce availability of similar jurisdictional measures this, per se, is already an encouraging feature. Secondly, even though the aggregate measures of Rule of Law and Regulatory Quality capture some additional aspects that are not central for our purposes, together they seem to cover the heart of the idea of jurisdictional uncertainty as defined in ABL. In other words, they include some noise in the analysis but they do not leave the crucial aspect of jurisdictional uncertainty - namely, the anti-credit/anti-saving 
Figure 7 - Jurisdictional Uncertainty Measures: Judicial Independence, Impartial Courts

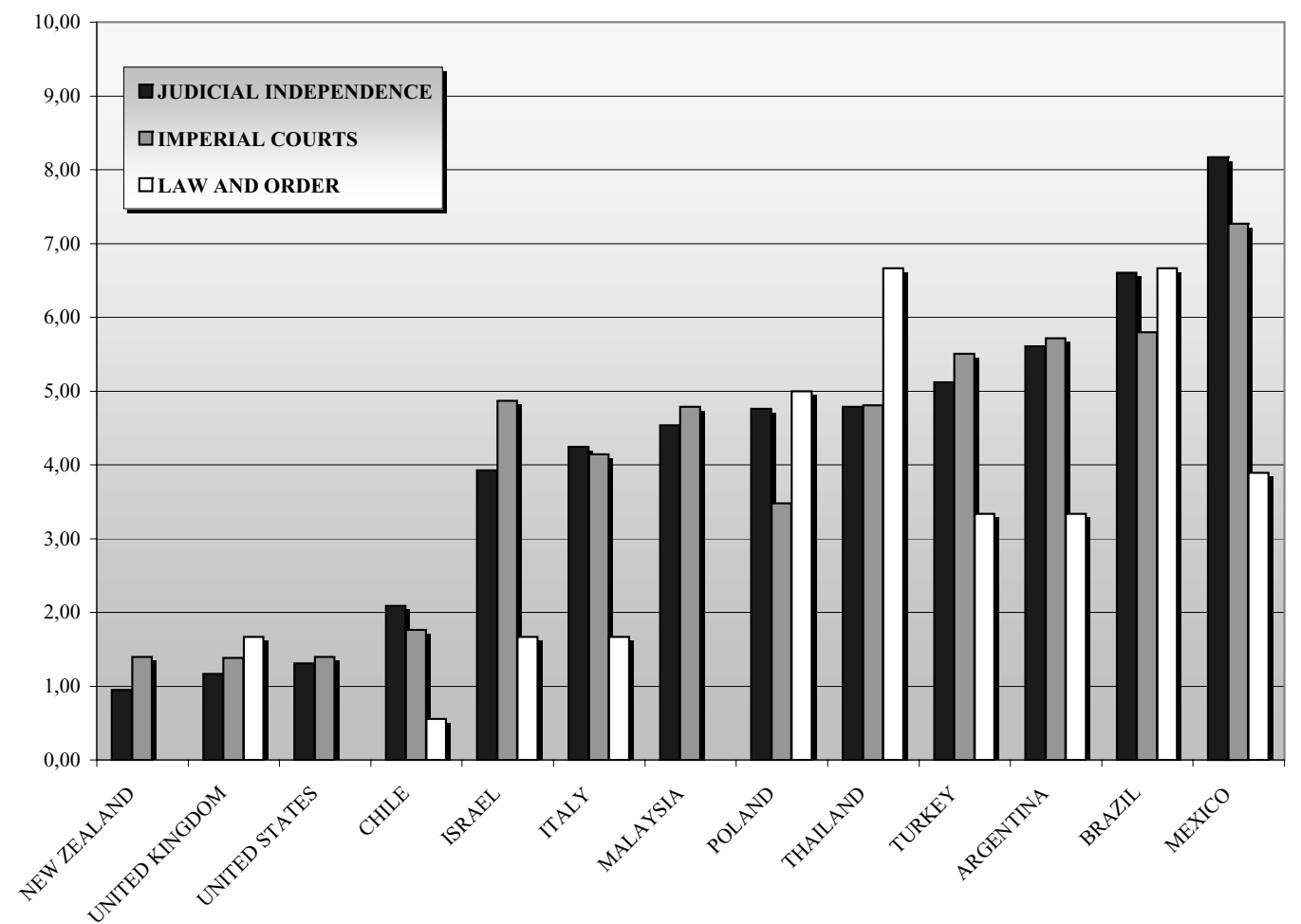

Source: Fraser Institute, Gwartney and Lawson (2004) and author's calculations. Note: Minimum is 0 and maximum is 10 , with higher values for higher jurisdictional uncertainty

bias - aside. Third and maybe more importantly, these World Bank indicators do not rely on only one primary source of Rule of Law or Regulatory Quality measures. For example, Table 2 summarizes the main sources used by the World Bank to calculate the Rule of Law observations for Brazil. ${ }^{16}$.

Therefore, for each country observation, the World Bank's Rule of Law and Regulatory Quality indicators build upon a wide range of primary sources, which tends to significantly reduce the probability of sampling measurement errors and is also an insurance against the possibility of biased methodologies. All of these desirable characteristics of the World Bank indicators make them a high-quality source of jurisdictional uncertainty measures.

Additionally, we also used an alternative source of institutional data. From the Fraser Institute database, which is based on the work of Gwartney and Lawson (2004), we obtained a comprehensive set of socio-economic data. These data are available in a 5-year frequency from 1970 to 1995 and then in an annual frequency from 1999 to 2002, for 123 countries. In 2000 the variables collected by the Fraser Institute that are related to institutional quality changed. This fact prevents any attempt to use this dataset to investigate the impact of institutional quality over a long period. However, for the years 2000, 2001, and 2002, a consistent set of some interesting institutional variables, such as judicial

16 The World Bank classifies the primary sources as polls of experts and surveys of business people or citizens in general, see Kaufmann et al. (2004) for advantages and disadvantages of each of these types of primary sources. 
Table 2 - Rule of Law for Brazil in 2002: List of 13 sources

\begin{tabular}{|ll|l|c|}
\hline & Source & Publication & Type \\
\hline 1. & Business Environment Risk Intelligence & Business Risk Service & Poll \\
2. & Columbia University & State Capacity Project & Poll \\
3. & World Bank & Country Policy and Institutional Assessments & Poll \\
4. & Global Insight's DRI McGraw-Hill & Country Risk Review & Poll \\
5. & Economist Intelligence Unit & Country Risk Service & Poll \\
6. & Gallup International & Voice of the People Survey & Survey \\
7. & World Economic Forum & Global Competitiveness Report & Survey \\
8. & Heritage Foundation/Wall Street Journal & Economic Freedom Index & Poll \\
9. & State Department / Amnesty International & Human Rights Report & Poll \\
10. & Political Risk Services & International Country Risk Guide & Poll \\
11. & Business Environment Risk Intelligence & Qualitative Risk Measure in Foreign Lending & Poll \\
12. & Institute for Management and Development & World Competitiveness Yearbook & Survey \\
13. & World Markets Research Center & World Markets Online & Poll \\
\hline
\end{tabular}

Source: World Bank, Kaufmann et al. (2004)

independence, impartial courts and integrity of the legal system, is available. The judicial independence variable measures whether "the judiciary is independent and not subject to interference by the government or parties in disputes." The impartial courts variable, for its turn, assesses if "a trusted legal framework exists for the private businesses to challenge the legality of government actions or regulations". At last, the integrity of the legal system variable evaluates not only the "strength and impartiality of the legal system" but also "the popular observance of the law", and is also referred to as 'law and order'. ${ }^{17}$ In all, thus, even though both sources of jurisdictional uncertainty measures described above have their own shortcomings when taken isolated, they are also to some extent complementary in terms of aggregation level and time span.

\subsection{Measuring Currency Inconvertibility}

Before we attempt to measure the degree of currency inconvertibility across countries, it is important to clarify what is meant by convertible currency. In terms of exchange rate regimes, the expression "full convertible currency" is often used to characterize the so-called hard pegs, such as the currency board system implemented in Argentina from 1991 to 2001, in which the Central Bank is obligated to convert one currency into another at a fixed parity established by law. It can also be used to characterize even extremer pegs such as those observed in dollarized economies (e.g. Panama) in which case the country totally forgoes having a domestic currency and simply uses a foreign currency instead.

However, as might be clear from previous sections, when we discuss convertibility in the present paper we are not referring to any fixed parity or hard peg exchange rate. Instead, we will use the term "currency inconvertibility" to refer to the existence of restrictions of any sort to convert domestic currency into foreign currency. In other words, we will be concerned with the existence of capital

\footnotetext{
${ }_{17}$ A third source of jurisdictional uncertainty measures that we investigated was obtained from La Porta et al. (1998), and contains four interesting institutional variables - efficiency of judicial system, rule of law, risk of expropriation and risk of contract repudiation for 49 countries - but only one observation per country (average between 1982 and 1995). Compared to the World Bank indicators, the variables in La Porta et al. (1998) have the advantage of offering disaggregated measures, which avoids the problem of unnecessary noise described above. On the other hand, the fact that only one observation is available per country has the significant shortcoming of not allowing us to control for country-specific effects in our regressions. For that reason, we opted not to emphasize the results obtained from that dataset and, to save space, we do not report them here (however, the results of the regressions using data from La Porta et al. (1998) are available from the authors upon request).
} 
controls that may prevent citizens to freely exchange assets with foreigners, in which case we call the currency "inconvertible". As discussed in section 2, capital controls in association with jurisdictional uncertainty are at the root of ABL's explanation to the high short-term interest rates in Brazil.

In order to measure the degree of currency inconvertibility in each country, we will use an index based on thirteen categories of capital control compiled by the IMF in its Annual Report on Exchange Arrangements and Exchange Restrictions (EAER). Each category measures a certain dimension of capital control. ${ }^{18}$ For each of the categories a value of 1 is attributed if there are capital controls of that type and a value of 0 is attributed otherwise. The index of currency inconvertibility (henceforth, INCONV) is built as follows:

$$
I N C O N V_{j}=10 \cdot\left(\frac{\sum_{i=1}^{13} D_{i j}}{13}\right)
$$

where $D_{i j}$ is the value of the dummy representing the i-th capital control category for the j-th country. Hence, the index of currency inconvertibility of a given country is proportional to the sum of the existent capital controls in each of the thirteen dimensions available. To obtain a 0-to-10 rating, the index is constructed by taking the average of the dummy variables (that is, by dividing by thirteen the sum of the number of capital controls existing in the country) and multiplying the result by ten. The bigger is the index, the more inconvertible is the currency of the country in the sense that it faces more restrictions to be converted into foreign assets. An index of 0 characterizes a perfectly convertible currency, as no type of capital control is levied in this case. At the other extreme, an index of 10 indicates that all thirteen types of capital control are present, meaning the maximum degree of capital control possible.

This index improves upon the frequently used dummy for capital controls, in which a country either has capital controls or not. By considering multiple dimensions of capital control it is possible to obtain an index that captures various degrees of currency inconvertibility. Indeed, because the index varies between 0 and 10, we can now rank countries according to their degree of capital control. As it will be described later, this feature will be particularly helpful in our empirical exercise, which uses fixed effects panels to test ABL's conjecture.

Figure 8 presents the currency inconvertibility index for selected countries. It shows that, while Brazil has substantially more capital controls in place than various developed economies, it is not an outlier compared to many developing economies.

\subsection{Other Determinants of the Short-Term Real Interest Rate}

In order to capture alternative possible causes for the real interest rate differentials between countries, we also run the regressions using variables that reflect more conventional views of why real interest rates may differ across countries and years. The main idea behind such controls is that, even if ABL's model captures some relationship between the pair jurisdictional uncertainty/currency inconvertibility and the real interest rate, such relation might be caused by omitted variables. Therefore, by looking at the significance of the coefficients of the original variables together with the controls, we should gain some insight as to what really are the crucial determinants of the real interest rate differentials in our sample.

\footnotetext{
${ }^{18}$ The categories are: controls on capital market securities, controls on money market instruments, controls on collective investment securities, controls on derivatives and other instruments, controls on commercial credits, controls on financial credits, controls on guarantees, sureties and financial backup facilities, controls on direct investment, controls on liquidation of direct investment, controls on real estate transactions, controls on personal capital movements, provisions specific to commercial banks and other credit institutions, and provisions specific to institutional investors.
} 
Figure 8 - Currency Inconvertibility Index: Selected Countries (Average 1996-2002)

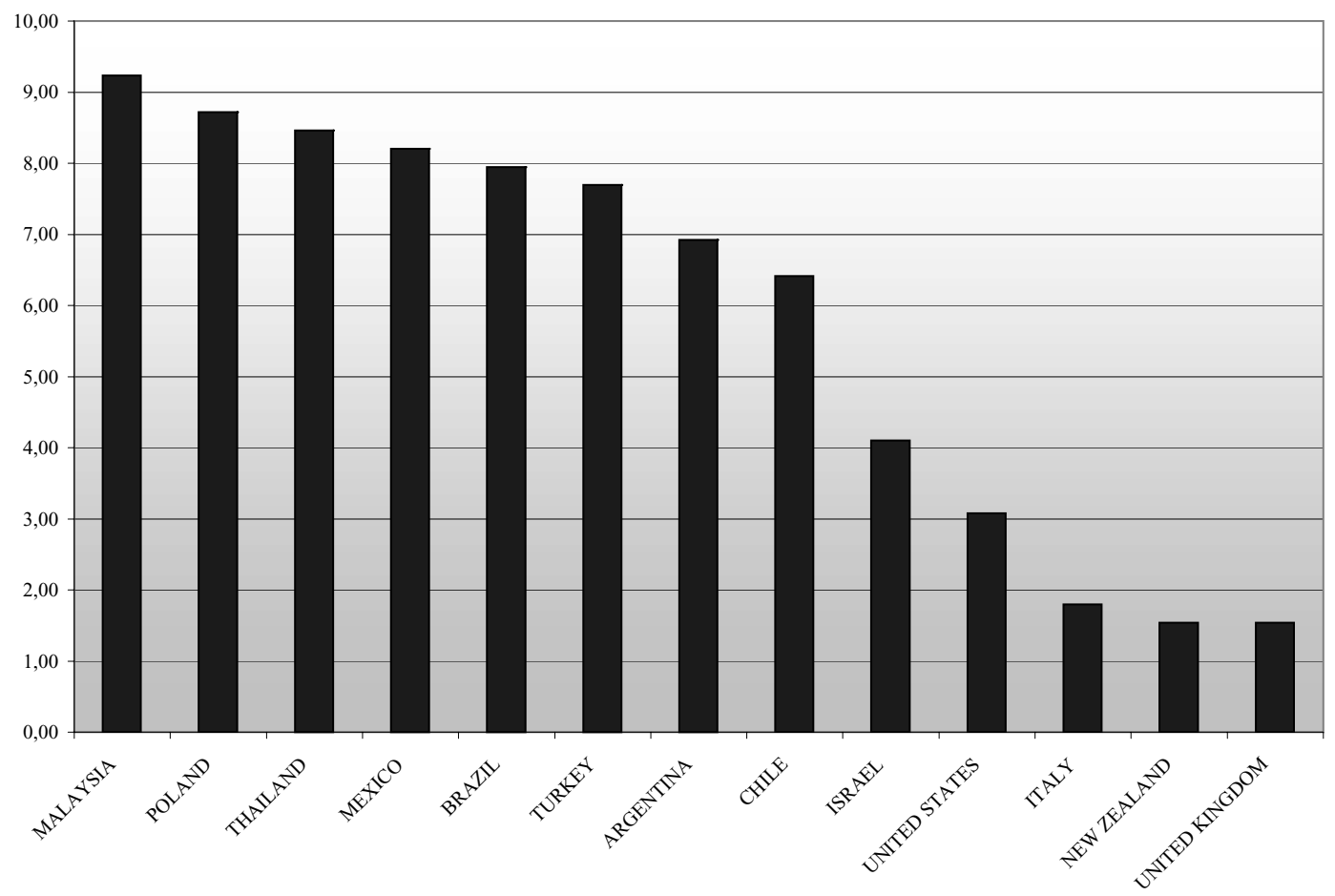

Source: IMF's EAER, Gwartney and Lawson (2004), and authors' calculations. Note: Minimum is 0 and maximum is 10 , with higher values for more inconvertible currencies

One possible omitted variable in ABL's model comes from the monetary front: countries with a bad arrangement of jurisdictional uncertainty/currency inconvertibility could have a high real interest rate not due to the direct effect of these variables, but because such a bad institutional arrangement could be strongly correlated with a poorly managed monetary policy. Note that the relationship theorized by ABL does not necessarily involve such monetary channel, as their definition of jurisdictional uncertainty is not directly linked with monetary policy considerations. Hence, as our monetary control variable we used the consumer inflation rate. ${ }^{19}$ The consumer inflation rate serves as a proxy of the preferences of the central bank (or, more generally, of the society), with higher inflation rates representing revealed preferences for loose monetary policy. ${ }^{20}$ Another possible omitted variable in ABL's model comes from the fiscal front: a bad jurisdiction might be related to high real interest rates not through a direct chan-

\footnotetext{
${ }^{19}$ We also experimented the standard deviation of consumer inflation (computed using averages of the previous 5 years), but it presented no significant explanatory power.

${ }^{20}$ However, inflation is not an ideal measure as it might suffer from endogeneity. An alternative measure of central banks' preferences would be an index of central bank independence but, to the best of our knowledge, there is no such index for a large sample of countries and covering recent years (for a recent paper on the topic of central bank independence, see Sturm and Haan, 2001). An apparent solution would be to use lagged inflation, but with annual frequency this might undermine our goal of capturing policymakers' current preferences toward inflation.
} 
nel, but because it may also be correlated with high levels of public debt. Similarly, then, we use a fiscal control variable to test the alternative hypothesis that fiscal dominance and debt dynamics aspects also play an important role in determining interest rate differentials between countries, regardless of their jurisdictional qualities. As a proxy of the countries' indebtedness of the public sector we rely on data from Callen et al. (2003), the Organisation for Economic Co-operation and Development (OECD), and central banks of the countries in our sample. ${ }^{21}$ We use these datasets to construct a measure of total debt (external plus domestic) as a share of GDP that we use as the fiscal control variable in our regressions.

Ultimately, what we will be able to test with our explanatory variables is (1) if there is a significant relationship between a country's jurisdictional uncertainty/currency inconvertibili-ty and its real interest rate level and (2) if there is such a relationship, could it be that it is just capturing the good old monetary and fiscal factors traditionally thought to be drivers of the real interest rate, regardless of the institutional arrangement in which they are inserted?

\subsection{The Sample}

As described before, there is a vast number of countries in both datasets we use (namely, 199 countries in the World Bank database and 123 countries in the Fraser Institute database). Indeed, both datasets cover a variety of economic experiences and regions that include the least developed countries in the world (LDCs), small islands, emerging market economies and developed countries. We chose not to include in our empirical investigation the LDCs and small islands, focusing instead in emerging market economies and developed countries. ${ }^{22,23}$

Our sample includes mostly those countries in J.P. Morgan Emerging Markets Bond Index Global (EMBI) and member countries of the Organization for Economic Cooperation and Development (OECD). This resulted in a sample size of 50 countries, roughly divided in half between emerging market economies and developed countries (see table 3). The sample is the same for both the World Bank and the Fraser Institute database. Hence, the only difference between regressions based on different databases is related to the period covered (1996, 1998, 2000, 2002 for the World Bank, and 2000, 2001, 2002 for the Fraser Institute) and the measures of jurisdictional uncertainty available in each database.

\section{TESTING ABL'S CONJECTURE AND ITS VARIANTS}

\subsection{Methodology}

In this section we outline the methodology used to empirically assess ABL's conjecture that jurisdictional uncertainty and capital account inconvertibility can significantly influence the level of short-term real interest rates. As argued in section 2.2, the following functional form for the short-term interest rate $r$ can generate ABL's conjecture and its variations depending on the signs and significance of the coefficients:

\footnotetext{
${ }^{21}$ The data collected by Callen et al. (2003) aims at obtaining the most comprehensive available measure of public sector debt, and contains annual data on 34 emerging market and 20 industrial countries for the period 1990-2002. For the emerging market's group, the coverage of the debt varies across countries (of the 34 countries, 19 have data for the public sector, 10 for the general government and 5 for central government), whereas industrial countries data are on a general government basis.

22 The LDCs often have a very small degree of monetization when compared to developing and developed economies. This reflects the fact that in these countries money is often not used as a means of exchange. Small islands tend to follow closely the monetary policy in bigger economies and often adopt hard pegs. These facts make their interest rates and monetary policy hard to compare to other countries and prevents any reliable cross-country empirical investigation on the determinants of short-term interest rates that includes them.

${ }^{23}$ In a preliminary stage of the paper, we used the full sample of countries in each database. The results were mixed and provided no clear-cut interpretation.
} 
Table 3 - Sample of Countries

\begin{tabular}{|c|c||c|c|}
\hline 1 & ALGERIA & 26 & JORDAN \\
2 & ARGENTINA & 27 & KOREA \\
3 & AUSTRALIA & 28 & MALAYSIA \\
4 & BOLIVIA & 29 & MEXICO \\
5 & BRAZIL & 30 & MOROCCO \\
6 & BULGARIA & 31 & NEW ZEALAND \\
7 & CANADA & 32 & NIGERIA \\
8 & CHILE & 33 & NORWAY \\
9 & CHINA,P.R.: MAINLAND & 34 & PAKISTAN \\
10 & COLOMBIA & 35 & PERU \\
11 & CROATIA & 36 & PHILIPPINES \\
12 & CZECH REPUBLIC & 37 & POLAND \\
13 & DENMARK & 38 & RUSSIA \\
14 & ECUADOR & 39 & SINGAPORE \\
15 & EGYPT & 40 & SLOVAK REPUBLIC \\
16 & FINLAND & 41 & SOUTH AFRICA \\
17 & GERMANY & 42 & SPAIN \\
18 & HUNGARY & 43 & SWEDEN \\
19 & ICELAND & 44 & SWITZERLAND \\
20 & INDIA & 45 & THAILAND \\
21 & INDONESIA & 46 & TURKEY \\
22 & IRELAND & 47 & UNITED KINGDOM \\
23 & ISRAEL & 48 & UNITED STATES \\
24 & ITALY & 49 & URUGUAY \\
25 & JAPAN & 50 & VENEZUELA, REP. BOL. \\
\hline & & \\
\hline
\end{tabular}

$$
r=\alpha+\beta \cdot J U+\gamma \cdot I N C O N V+\delta \cdot J U \cdot I N C O N V
$$

where $r$ is the short-term real interest rate, $J U$ measures the degree of jurisdictional uncertainty, $I N C O N V$ measures the degree of currency inconvertibility and $J U \cdot I N C O N V$ captures the interaction effect between these two variables. Hence, to evaluate whether ABL's conjecture and its variants are empirically valid or not, we explore the panel structure of our datasets to estimate the following equation:

$$
r_{i t}=\alpha_{i}+\lambda_{t}+\beta \cdot J U_{i t}+\gamma \cdot I N C O N V_{i t}+\delta \cdot\left(J U_{i t} \cdot I N C O N V_{i t}\right)+\epsilon_{i t}
$$

where $\epsilon$ is the error term and $i$ and $t$ are indexes for country and year respectively. It is important to note that the empirical specification above includes country-specific coefficients, $\alpha_{i}$, and time effects, $\lambda_{t}$, which are essential to control for unobserved variables that might be influencing real interest rates in each country and in each year respectively. Thanks to the panel structure of our datasets we are able to perform fixed-effects estimations in order to control for country-specific effects. Time effects are also important to control for different conditions affecting all countries in a given year (for example, international liquidity conditions). The inclusion of these controls help preventing omitted variable bias in our estimations.

As described in section 2.2, depending on whether ABL's conjecture or any of its variants are correct, the significance and the sign of the parameters in the equation above are expected to be as follows: 


\section{ABL's conjecture}

- $\beta>0$ and significant

- $\gamma$ not significantly different from 0

- $\delta>0$ and significant

\section{Variant 1}

- $\beta>0$ and significant

- $\gamma>0$ and significant

- $\delta>0$ and significant

\section{Variant 2}

- $\beta>0$ and significant

- $\gamma>0$ and significant

- $\delta$ not significantly different from 0

Variant 3

- $\beta$ not significantly different from 0

- $\gamma>0$ and significant

- $\delta>0$ and significant

In what follows, we test ABL's conjecture as well as these three variants.

\subsection{Estimation Results}

To measure the degree of inconvertibility of the currency we use our index on capital controls described on section 3.2. In the case of jurisdictional uncertainty, as we previously noted, obtaining a single measure that captures the concept as defined by ABL is not an easy task and, for that reason, we rely on various measures from two different databases. ${ }^{24}$

Tables 4 and 5 show the results of our estimations with fixed and time effects. ${ }^{25}$ The dependent variable in all estimations is the short-term real interest rate. Table 4 presents regressions using the two measures of jurisdictional uncertainty obtained from Kaufmann et al. (2004) from the World Bank (Rule of Law and Regulatory Quality), while Table 5 presents regressions that use the three measures of jurisdictional uncertainty obtained from Gwartney and Lawson (2004) from the Fraser Institute (Judicial Independence, Impartial Courts, and Law and Order). In both tables, columns 1-4 present regressions based of ABL's conjecture and its three variants. Columns 5-8 repeat the regressions of the previous columns adding the inflation rate and total public debt-to-GDP ratio as controls.

Examining at first columns 1-4 in both tables, it becomes immediately clear that none of our five measures of jurisdictional uncertainty provides strong evidence in favor of ABL's conjecture or any of its variants. In fact, only in the cases of Judicial Independence and only for variant 2 , were we able to

\footnotetext{
${ }^{24}$ We also performed principal components analysis for both datasets in an attempt to reduce the number of jurisdictional uncertainty measures we have by obtaining their common factors. The results were not substantially different from the analysis of each measure separately and are not shown here in order to save space.

${ }^{25}$ Fixed and time effects coefficients were omitted from the tables.
} 
obtain significant coefficients for the jurisdictional uncertainty measure at a $5 \%$ level. It is somewhat surprising that none of the five jurisdictional uncertainty measures are significant at least when directly included, under ABL's original conjecture (column 1) or under its variant 1 and 2 (columns 2 and 3 respectively). It should be noted, however, that, except for Law and Order, all jurisdictional uncertainty variables, despite not having significant coefficients in most cases, were always positively correlated to the short-term real interest rate levels (i.e., presented the expected sign as predicted by ABL).

In the case of the interaction term and the inconvertibility index, the results provide even weaker evidence in favor of ABL's predictions. Indeed, the coefficient of the interaction term was significant and positive only in the case of variant 3 and exclusively for Judicial Independence. In all other cases, the coefficient on the interaction term was not significant and, in many instances, it had a negative sign, contrary to what ABL predicted. The coefficient of the inconvertibility index, for its turn, is never significant at customary levels and, similarly to the interaction term, it often presents a negative sign, in discordance with ABL's arguments.

In columns 5-8 we include our monetary and fiscal policy controls (inflation and total public debtto-GDP ratio, respectively). For both controls we obtain very significant coefficients in all cases. For the jurisdictional uncertainty measures, the results become even less conclusive than in the regressions without controls, with the only variable found significant before (Judicial Independence, variant 2) now losing significance and with some jurisdictional uncertainty coefficients now having negative signs. Interestingly, we now find that the coefficient of Law and Order, which is the only jurisdictional uncertainty measure that is significant in the regressions that include controls, has a negative sign, implying that more jurisdictional uncertainty would be related to lower real interest rates. ${ }^{26}$

The inclusion of monetary and fiscal controls does not modify the significance and sign of the coefficient of the interaction term of Judicial Independence's variant 3. On the contrary, we now find that the interaction term for Judicial Independence also becomes significant for ABL's original conjecture as well. For all other jurisdictional uncertainty measures there is no clear-cut evidence in favor of ABL's argument, with the coefficients of the interaction term being not significant at the $5 \%$ level and often having a negative sign.

The coefficients of the inconvertibility index still present evidence not favorable to ABL's arguments after the inclusion of the monetary and fiscal controls. Only in the case of Law and Order's variant 3 we obtain a positive and significant coefficient (at a 5\% level) for the inconvertibility index as ABL predicted. In all other cases, the coefficient of the inconvertibility index is not significant at a $5 \%$ level and sometimes presents a negative sign, contradicting ABL.

All in all, our results reject ABL's conjecture and its variants, showing that jurisdictional uncertainty, currency inconvertibility and their interaction cannot satisfactorily explain the short-term real interest rate dispersion observed in our sample. If anything, our results show that monetary and fiscal factors are much more important determinants of the level of short-term real interest rate. It should be noted that the coefficients on the control variables are not only significant in all regressions, but they also have always the same sign: negative for the inflation rate and positive for total debt-to-GDP ratio. The negative connection between real interest rates and inflation points to the fact that, after controlling for other factors, real interest rates are lower in countries that are less willing to combat inflation (and, hence, have higher inflation rates). For its turn, the positive sign on the coefficients of total debt-to-GDP ratio indicates that larger debt stocks result in larger real interest rate. It should also be noted that the $\mathrm{R}$-square of the regressions improve substantially in both datasets when the two controls are included: in the case of the World Bank dataset it goes from less than $5 \%$ to above $20 \%$ and in the case of the Fraser Institute dataset it rises from less than $5 \%$ to almost $40 \%$.

Some readers might find surprising the negative sign we obtained for inflation and for that reason a comparison with previous works is warranted. In fact, the empirical literature on interest rate rules

\footnotetext{
${ }^{26}$ If a bad jurisdiction also implies a low degree of independence of the central bank and/or a weaker willingness to combat inflation, a negative relation between jurisdictional uncertainty and the level of real interest rates could result.
} 
Table 4 - Econometric Results: World Bank Dataset (1996-2002)

\begin{tabular}{|c|c|c|c|c|c|c|c|c|c|c|c|}
\hline \multicolumn{12}{|c|}{ Dependent Variable: Real Interest Rate } \\
\hline & \multicolumn{4}{|c|}{ ABL's Conjecture and Its Variants } & \multicolumn{7}{|c|}{ Including Monetary and Fiscal Policy Controls } \\
\hline & $\begin{array}{l}\mathrm{ABL} \\
(1)\end{array}$ & $\begin{array}{c}\text { Variant } 1 \\
(2)\end{array}$ & $\begin{array}{c}\text { Variant } 2 \\
(3)\end{array}$ & $\begin{array}{c}\text { Variant } 3 \\
(4)\end{array}$ & $\begin{array}{l}\text { ABL } \\
(5)\end{array}$ & $\begin{array}{c}\text { Variant } 1 \\
(6)\end{array}$ & & $\begin{array}{c}\text { Variant } 2 \\
(7)\end{array}$ & & $\begin{array}{c}\text { Variant } 3 \\
(8)\end{array}$ & \\
\hline Jurisdictional Uncertainty (JU) & $\begin{array}{c}0,107 \\
(0,148)\end{array}$ & $\begin{array}{c}0,145 \\
(0,181)\end{array}$ & $\begin{array}{c}0,139 \\
(0,116)\end{array}$ & & $\begin{array}{c}0,079 \\
(0,167)\end{array}$ & $\begin{array}{c}0,102 \\
(0,199)\end{array}$ & & $\begin{array}{c}0,046 \\
(0,132)\end{array}$ & & & \\
\hline Interaction Term (JU*INCONV) & $\begin{array}{c}0,005 \\
(0,011)\end{array}$ & $\begin{array}{l}-0,001 \\
(0,018)\end{array}$ & & $\begin{array}{c}0,010 \\
(0,012)\end{array}$ & $\begin{array}{l}-0,004 \\
(0,011)\end{array}$ & $\begin{array}{l}-0,007 \\
(0,018)\end{array}$ & & & & $\begin{array}{l}0,0001 \\
(0,012)\end{array}$ & \\
\hline Inconvertibility (INCONV) & & $\begin{array}{c}0,285 \\
(0,775)\end{array}$ & $\begin{array}{c}0,259 \\
(0,478)\end{array}$ & $\begin{array}{l}-0,692 \\
(0,635)\end{array}$ & & $\begin{array}{c}0,167 \\
(0,763)\end{array}$ & & $\begin{array}{l}-0,059 \\
(0,473)\end{array}$ & & $\begin{array}{c}-0,045 \\
(0,945)\end{array}$ & \\
\hline Inflation Rate & & & & & $\begin{array}{l}-0,275^{* * *} \\
(0,050)\end{array}$ & $\begin{array}{l}-0,275 \\
(0,050)\end{array}$ & *** & $\begin{array}{l}-0,273 \\
(0,050)\end{array}$ & *** & $\begin{array}{c}-0,274 \\
(0,050)\end{array}$ & *** \\
\hline Total Debt-to-GDP Ratio & & & & & $\begin{array}{l}0,131^{\text {**** }} \\
(0,049)\end{array}$ & $\begin{array}{c}0,130 \\
(0,049)\end{array}$ & *** & $\begin{array}{c}0,131 \\
(0,049)\end{array}$ & *** & $\begin{array}{c}0,139 \\
(0,046)\end{array}$ & *** \\
\hline no. of observations & 200 & 200 & 200 & 200 & 181 & 181 & & 181 & & 181 & \\
\hline no. of countries & 50 & 50 & 50 & 50 & 46 & 46 & & 46 & & 46 & \\
\hline $\mathrm{R} 2$ & 0,037 & 0,038 & 0,038 & 0,033 & 0,228 & 0,228 & & 0,227 & & 0,226 & \\
\hline \multicolumn{12}{|l|}{$\mathrm{JU}=$ Regulatory Quality } \\
\hline Jurisdictional Uncertainty (JU) & $\begin{array}{c}0,124 \\
(0,112)\end{array}$ & $\begin{array}{c}0,240 \\
(0,140)\end{array}$ & $\begin{array}{c}* 0,075 \\
(0,072)\end{array}$ & & $\begin{array}{c}0,125 \\
(0,126)\end{array}$ & $\begin{array}{c}0,247 \\
(0,153)\end{array}$ & & $\begin{array}{c}-0,002 \\
(0,087)\end{array}$ & & & \\
\hline Interaction Term (JU*INCONV) & $\begin{array}{l}-0,006 \\
(0,012)\end{array}$ & $\begin{array}{l}-0,023 \\
(0,017)\end{array}$ & & $\begin{array}{c}0,002 \\
(0,844)\end{array}$ & $\begin{array}{l}-0,016 \\
(0,011)\end{array}$ & $\begin{array}{l}-0,033 \\
(0,017)\end{array}$ & * & & & $\begin{array}{l}-0,011 \\
(0,010)\end{array}$ & \\
\hline Inconvertibility (INCONV) & & $\begin{array}{c}0,963 \\
(0,698)\end{array}$ & $\begin{array}{c}0,264 \\
(0,479)\end{array}$ & $\begin{array}{c}0,245 \\
(0,562)\end{array}$ & & $\begin{array}{c}0,967 \\
(0,693)\end{array}$ & & $\begin{array}{c}0,040 \\
(0,473)\end{array}$ & & $\begin{array}{c}0,327 \\
(0,572)\end{array}$ & \\
\hline Inflation Rate & & & & & $\begin{array}{l}-0,283^{* * *} \\
(0,050)\end{array}$ & $\begin{array}{l}-0,282 \\
(0,050)\end{array}$ & *** & $\begin{array}{l}-0,274 \\
(0,050)\end{array}$ & *** & $\begin{array}{l}-0,278 \\
(0,050)\end{array}$ & *** \\
\hline Total Debt-to-GDP Ratio & & & & & $\begin{array}{l}0,137^{\text {*** }} \\
(0,052)\end{array}$ & $\begin{array}{c}0,136 \\
(0,052)\end{array}$ & *** & $\begin{array}{c}0,140 \\
(0,052)\end{array}$ & *** & $\begin{array}{c}0,164 \\
(0,049)\end{array}$ & *** \\
\hline no. of observations & 200 & 200 & 200 & 200 & 181 & 181 & & 181 & & 181 & \\
\hline no. of countries & 50 & 50 & 50 & 50 & 46 & 46 & & 46 & & 46 & \\
\hline R2 & 0,035 & 0,048 & 0,035 & 0,028 & 0,238 & 0,2493 & & 0,226 & & 0,234 & \\
\hline
\end{tabular}

Notes: standard errors in parentheses. ${ }^{*}$ significant at $10 \% ;{ }^{* *}$ significant at $5 \%$; ${ }^{* * *}$ significant at $1 \%$. 
Table 5 - Econometric Results: Fraser Institute Dataset (2000-2002)

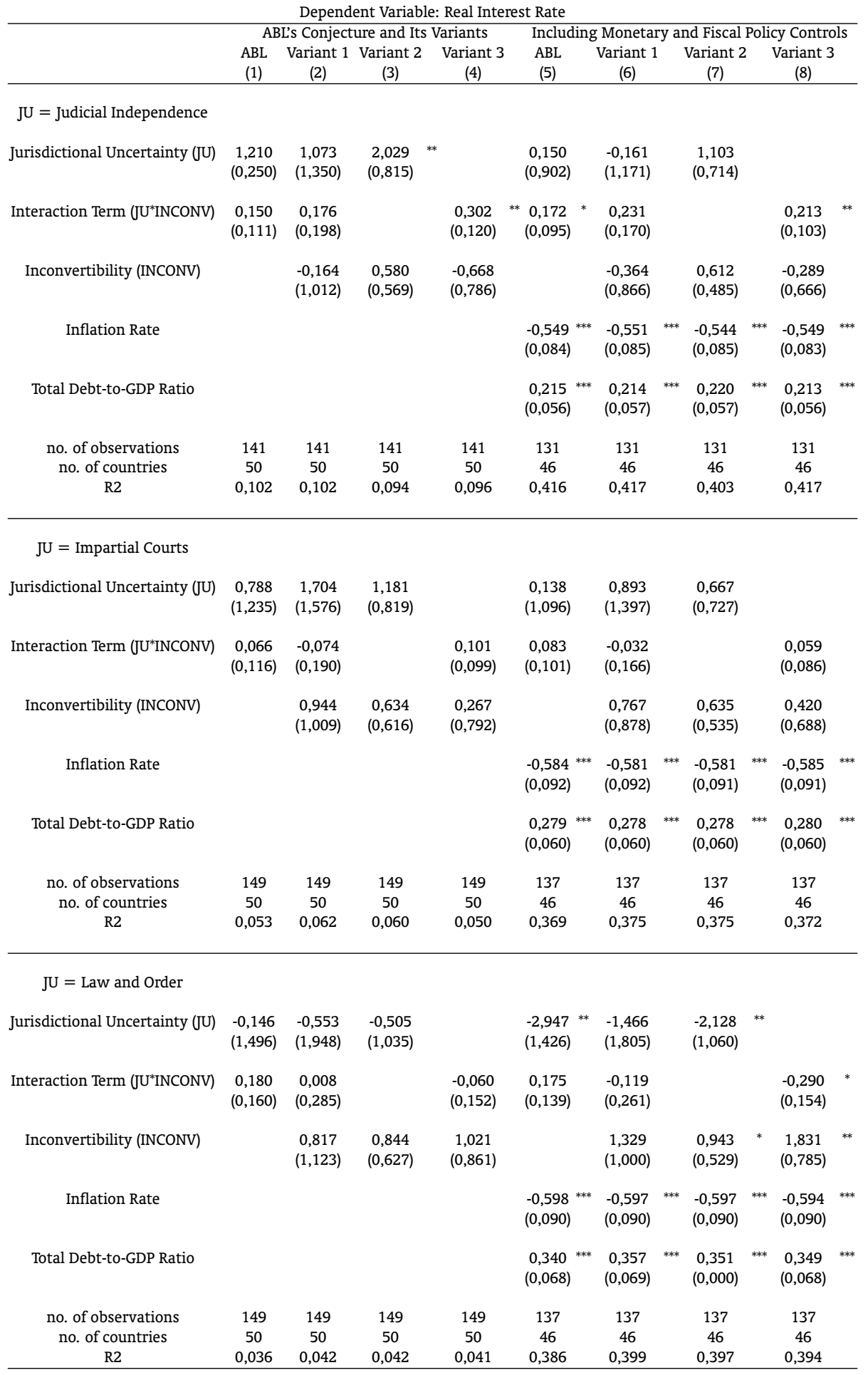

Notes: standard errors in parentheses. ${ }^{*}$ significant at $10 \% ;{ }^{* *}$ significant at $5 \%$; ${ }^{* * *}$ significant at $1 \%$. 
that followed from the seminal work by Taylor (1993) often establishes coefficients for inflation that are larger than one in regressions where the short-term nominal interest rate (the monetary policy instrument) is the dependent variable. ${ }^{27}$ In these cases, monetary policy is said to be non-accommodative in the sense that nominal interest rates respond more than one-to-one to inflation, meaning that there is a tendency of raising (reducing) the real interest rate in response to an increase (decrease) in inflation. However, we argue that this positive relation between real interest rates and inflation found in the interest rate rules literature, which is seemingly inconsistent with our findings, is actually the result of fundamental differences between this literature's empirical approach and ours.

First, an important difference is the frequency of the data. Our exercise uses yearly observations, whereas the interest rate rule literature relies on higher frequency data (monthly or even higher). Second, our regressions are based on a panel of countries, whereas the interest rate rule literature usually focus on one country at a time. These differences imply that, while the interest rate rule literature capture the short-term reaction of monetary policy to changes in the inflation rate, we capture crosscountry differences in preferences toward inflation.

A thorough investigation of our finding that both monetary and fiscal factors are relevant determinants of real interest rates go beyond the purposes of this paper and are left for future research. The relative importance of these factors, as pointed out by our results, indicates that this might be a fruitful avenue of research.

\section{CONCLUSIONS}

The phenomenon of high and persistent short-term real interest rates in Brazil has stimulated an extensive literature attempting to explain its causes. Among the various contributions on the topic, one that has been receiving considerable attention is an article by ABL, which considers the impact of jurisdictional uncertainty and currency inconvertibility on the level of short-term real interest rates.

In the present paper, we formulated a methodology based on ABL's definition of jurisdictional uncertainty, collected variables that proxy the degree of jurisdictional uncertainty, built an index of currency inconvertibility and used them to test ABL's conjecture and variants of it. The results are by and large unfavorable not only to ABL's conjecture, but also to variants of their argument.

On the other hand, we found statistically significant correlations of the short-term real interest rate with inflation and total public debt-to-GDP ratio. From this result, we can conclude that traditional monetary and fiscal factors are far more relevant to explain the level of short-term real interest rates than the binomial jurisdictional uncertainty/currency inconvertibility is.

While further investigations about the connection between short-term real interest rates and monetary and fiscal factors are warranted, it is also important to recognize the limitations of our empirical exercise in evaluating ABL's conjecture. We see such limitations coming basically from two fronts.

First, the absence of a variable that captures without noise the anti-creditor/anti-saving bias emphasized by ABL is a potentially important shortcoming. As we emphasized before, the inability to control for country-specific effects undermines the confidence in econometric results based on potentially better measures, such as the ones in La Porta et al. (1998), which specifically capture for instance the risk of expropriation and risk of contract repudiation for 49 countries but for only one time period. Due to this limitation in the time span we had to abort any attempt to seriously explore this alternative data set. ${ }^{28}$

A second important shortcoming in our results is that we did not directly consider in our regressions some factors claimed by ABL as aggravators of the negative impact of jurisdictional uncertainty on the

\footnotetext{
${ }^{27}$ See the volume edited by Taylor (1999) for a more recent review of the literature on monetary policy rules.

${ }^{28}$ A similar problem affects other alternative measures that have been suggested to us, such as the ones in the World Bank's 2005 Doing Business report related to "getting credit" and "enforcing contracts", which also cover only one year for each country and fall into the same kind of constraint we faced with La Porta et al. (1998).
} 
short-term interest rate in Brazil, in addition to the currency inconvertibility. Namely, these factors are the artificial lengthening of public debt maturities, compulsory saving funds and distorting taxation (all of them are discussed in detail in $\mathrm{ABL}$ ). The difficulties in adapting those specific Brazilian factors to our panel data empirical exercise explain their absence from this paper, given that it is very hard to find similar data for other countries. Although we recognize that an exhaustive assessment of ABL's conjecture would necessarily have to take those factors into account, we still find hard to believe that the very low significance of the jurisdictional uncertainty measures we found in all variants of our analysis would change substantially if any of those factors could somehow be included. In fact, one should expect that the aggravating factors cited by ABL are highly correlated with the quality of institutions and, hence, with our measures of jurisdictional uncertainty.

That said, in our view these are still two important sets of limitations in our results that could be fertile ground for future research on the impact of jurisdictional uncertainty on short-term real interest rates.

\section{Bibliography}

Acemoglu, D. \& Johnson, S. (2005). Unbundling institutions. Journal of Political Economy, 113(5):949-995. available at http://ideas.repec.org/a/ucp/jpolec/v113y2005i5p949-995.html.

Arida, P. (2003a). Ainda sobre conversibilidade. Revista de Economia Politica, 23(3).

Arida, P. (2003b). Por uma moeda plenamente conversivel. Revista de Economia Politica, 23(3).

Arida, P., Bacha, E., \& Lara-Resende, A. (2005). Credit, interest, and jurisdictional uncertainty: Conjectures on the case of brazil. In Inflation Targeting and Debt: The Case of Brazil. MIT Press.

Belluzzo, L. G. \& Carneiro, R. (2004). O mito da conversibilidade. Revista de Economia Politica, 24(2).

Blanchard, O. (2004). Fiscal dominance and inflation targeting: Lessons from brazil. In Inflation Targeting and Debt: The Case of Brazil. MIT Press.

Bonomo, M. A. C. \& Brito, R. D. (2002). Regras monetárias e dinâmica macroeconômica no brasil: Uma abordagem de expectativas racionais. Revista Brasileira de Economia, 56(4). available at http://ideas.repec.org/a/fgv/epgrbe/3978.html.

Caballero, R. J. \& Krishnamurthy, A. (2002). A dual liquidity model for emerging markets. American Economic Review, 92(2):33-37. available at http://ideas.repec.org/a/aea/aecrev/v92y2002i2p33-37.html.

Callen, T., Terrones, M., Debrun, X., Daniel, J., \& Allard, C. (2003). Public Debt in Emerging Markets: Is It Too High?, chapter III. World Economic Outlook.

Eichengreen, B. \& Hausmann, R. (1999). Exchange rate and financial fragility. In New Challenges for Monetary Policy, pages 329-68. Federal Reserve Bank of Kansas City, Kansas City.

Eichengreen, B., Hausmann, R., \& Panizza, U. (2004). Original sin: the road to redemption. In Other People's Money: Debt Denomination and Financial Instability in Emerging Market Economies. University of Chicago Press.

Favero, C. A. \& Giavazzi, F. (2002). Why are brazil's interest rates so high? Working Papers 224, IGIER (Innocenzo Gasparini Institute for Economic Research), Bocconi University. available at http://ideas.repec.org/p/igi/igierp/224.html.

Garcia, M. (2004). Brazil in the 21st century: How to escape the high real interest trap. texto para discussão, Departamento de Economia PUC-Rio, Rio de Janeiro. 
Gwartney, J. \& Lawson, R. (2000-2004). Economic freedom of the world: 2004 annual report. www.freetheworld.com.

Hillbrecht, R. (2001). Metas de inflação e política fiscal. Revista Brasileira de Economia, 55(3).

Kanczuk, F. (2002). Juros reais e ciclos reais brasileiros. Revista Brasileira de Economia, 52(2).

Kaufmann, D., Kraay, A., \& Mastruzzi, M. (2004). Governance matters iii: Governance indicators for 1996, 1998, 2000, and 2002. World Bank Economic Review, 18(2):253-287. available at http://ideas.repec.org/a/oup/wbecrv/v18y2004i2p253-287.html.

La Porta, R., de Silanes, F. L., Schleifer, A., \& Vishny, R. (1998). Law and finance. Journal of Political Economy, 106(6).

North, D. (1981). Structure and Change in Economic History. W.W. Norton \& Co, New York.

Oreiro, J. L., de Paula, L. F., \& da Silva, G. (2004). Por uma moeda parcialmente conversível: uma crítica a arida e bacha. Revista de Economia Política, 24(2).

Pinheiro, A. C. \& Cabral, C. (2001). Credit markets in brazil: The role of the judiciary and other institutions. In Defusing Default: Incentives and Institutions. IDB/OCDE.

Rocha, F. \& Picchetti, P. (2005). Fiscal adjustment in brazil. Revista Brasileira de Economia, 57(1).

Salgado, M. J., Garcia, M., \& Medeiros, M. (2005). Monetary policy during brazil's real plan: estimating the central bank's reaction function. Revista Brasileira de Economia, 59(1).

Taylor, J. B. (1993). Discretion versus policy rules in practice. Carnegie-Rochester Conference Series on Public Policy, 39:195-214. available at http://ideas.repec.org/a/eee/crcspp/v39y1993ip195-214.html.

Taylor, J. B. (1999). Monetary policy rules. Technical report, University of Chicago Press.

\section{A. APPENDIX}


Table 6 - Descritpion of the Variables

\begin{tabular}{|c|c|c|c|c|}
\hline Variable & Description & Scale & Sources & Years \\
\hline Short-Term Real Interest Rate & $\begin{array}{l}\text { Real expost interest rates ob- } \\
\text { tained from the nominal in- } \\
\text { terest rates deflated by the } \\
\text { consumer prices. As nominal } \\
\text { interest rates we used money } \\
\text { market rates when possible, } \\
\text { and treasury discount rates } \\
\text { otherwise. }\end{array}$ & percent & $\begin{array}{l}\text { IMF's International Financial } \\
\text { Statistics, authors' calcula- } \\
\text { tions. }\end{array}$ & 1996-2002 \\
\hline \multicolumn{5}{|l|}{ JU measures - WB } \\
\hline $\begin{array}{l}\text { Rule of Law Measure the ex- } \\
\text { tent to which agents have } \\
\text { confidence in and abide by } \\
\text { the rules of society. These in- } \\
\text { clude perceptions of the in- } \\
\text { cidence of crime, the effec- } \\
\text { tiveness and predictability of } \\
\text { the judiciary and the enforce- } \\
\text { ment of contracts. }\end{array}$ & $\begin{array}{l}0 \text { to } 100 \text {, with higher scores } \\
\text { for worse rule of law. }\end{array}$ & $\begin{array}{l}\text { Kaufmann et al. (2004) - } \\
\text { World Ban }\end{array}$ & $1996,1998,2000$ and 2002 & \\
\hline Regulatory Quality & $\begin{array}{l}\text { Includes measures of inci- } \\
\text { dence of market-unfriendly } \\
\text { policies such as price controls } \\
\text { or inadequate bank supervi- } \\
\text { sion, as well as perceptions } \\
\text { imposed by excessive regula- } \\
\text { tion in areas such as foreign } \\
\text { trade and business develop- } \\
\text { ment. }\end{array}$ & $\begin{array}{l}0 \text { to } 100 \text {, with higher scores } \\
\text { for worse regulatory quality. }\end{array}$ & $\begin{array}{l}\text { Kaufmann et al. (2004) - } \\
\text { World Bank }\end{array}$ & $1996,1998,2000$ and 2002 \\
\hline \multicolumn{5}{|l|}{ JU measures - Fraser } \\
\hline $\begin{array}{l}\text { Judicial Independence Mea- } \\
\text { sures whether the judiciary } \\
\text { is independent and not sub- } \\
\text { ject to interference by the } \\
\text { government or parties in dis- } \\
\text { putes. }\end{array}$ & $\begin{array}{l}0 \text { to } 10 \text {, with higher scores } \\
\text { representing a less indepen- } \\
\text { dent judiciary. }\end{array}$ & $\begin{array}{l}\text { Gwartney and Lawson (2000- } \\
\text { 2004) - Fraser Institute }\end{array}$ & 2000,2001 , and 2002 & \\
\hline Impartial Courts & $\begin{array}{l}\text { Assesses if a trusted legal } \\
\text { framework exists for the pri- } \\
\text { vate businesses to challenge } \\
\text { the legality of government } \\
\text { actions or regulations. }\end{array}$ & $\begin{array}{l}0 \text { to } 10 \text {, with higher scores } \\
\text { representing lower quality of } \\
\text { legal framework. }\end{array}$ & $\begin{array}{l}\text { Gwartney and Lawson (2000- } \\
\text { 2004) - Fraser Institute }\end{array}$ & 2000,2001 , and 2002 \\
\hline $\begin{array}{l}\text { Law and Order Evaluates not } \\
\text { only the strength and impar- } \\
\text { tiality of the legal system but } \\
\text { also the popular observance } \\
\text { of the law. }\end{array}$ & $\begin{array}{l}0 \text { to } 10 \text {, with lower scores } \\
\text { representing weaker and } \\
\text { more impartial systems. }\end{array}$ & $\begin{array}{l}\text { Gwartney and Lawson (2000- } \\
\text { 2004) - Fraser Institute }\end{array}$ & 2000,2001 , and 2002 & \\
\hline \multicolumn{5}{|l|}{ INCONV measure } \\
\hline $\begin{array}{l}\text { Currency Inconvertibility In- } \\
\text { dex }\end{array}$ & $\begin{array}{l}\text { Restrictions on the freedom } \\
\text { of citizens to engage in cap- } \\
\text { ital market exchange with } \\
\text { foreigners - index of capital } \\
\text { controls among } 13 \text { IMF cate- } \\
\text { gories. }\end{array}$ & $\begin{array}{l}0 \text { to } 10 \text {, with higher scores } \\
\text { for more controls. }\end{array}$ & $\begin{array}{l}\text { IMF's EAER, author's calcula- } \\
\text { tions and Fraser Institute. }\end{array}$ & $\begin{array}{l}1996,1998,2000,2001 \text { and } \\
2002\end{array}$ \\
\hline \multicolumn{5}{|l|}{ Monetary Policy } \\
\hline Inflation Rate & CPI inflation rate. & percent & $\begin{array}{l}\text { IMF's International Financial } \\
\text { Statistics, authors' calcula- } \\
\text { tions. }\end{array}$ & $1996-2002$ \\
\hline \multicolumn{5}{|l|}{ Fiscal Policy } \\
\hline Total Debt-to-GDP ratio & $\begin{array}{l}\text { Public debt (domestic and ex- } \\
\text { ternal) as a share of GDP. }\end{array}$ & percent & $\begin{array}{l}\text { Callen et al. (2003), OECD and } \\
\text { central banks. }\end{array}$ & $1996-2002$ \\
\hline
\end{tabular}


Table 7 - Variables (Average 1996-2002)

\begin{tabular}{|c|c|c|c|c|c|c|c|c|c|}
\hline Countries & Real Interest Rate & Inconvertibilty & Inflation Rates & Debt To Gdp & Ruleoflaw & Regquality & Jud_Ind & Courts & Laworder \\
\hline ALGERIA & 3,54 & 8,54 & 6,35 & & 27,40 & 20,95 & 3,00 & 3,78 & 3,33 \\
\hline ARGENTINA & 8,34 & 6,92 & 6,50 & 68,28 & 55,68 & 62,23 & 1,83 & 2,73 & 6,11 \\
\hline AUSTRALIA & 2,86 & 7,18 & 2,74 & 30,34 & 95,05 & 93,38 & 9,29 & 8,79 & 10,00 \\
\hline BOLIVIA & 5,40 & 2,72 & 6,41 & & 37,13 & 72,23 & 1,56 & 2,44 & 5,00 \\
\hline BRAZIL & 13,51 & 7,95 & 8,61 & 63,56 & 52,08 & 61,25 & 5,21 & 5,19 & 3,33 \\
\hline BULGARIA & $-6,05$ & 7,21 & 39,10 & 88,20 & 55,88 & 59,23 & 4,18 & 4,51 & 6,67 \\
\hline CANADA & 2,32 & 1,54 & 1,89 & 88,42 & 94,50 & 90,68 & 8,50 & 7,90 & 10,00 \\
\hline CHILE & 1,63 & 6,41 & 4,70 & 17,89 & 86,55 & 91,70 & 5,75 & 5,86 & 8,33 \\
\hline CHINA & 3,14 & 9,01 & 1,74 & 19,31 & 47,05 & 41,88 & 4,31 & 4,91 & 7,22 \\
\hline COLOMBIA & 5,44 & 10,00 & 13,62 & 40,38 & 31,40 & 60,75 & 3,64 & 4,65 & 1,67 \\
\hline CROACIA & 4,68 & 9,02 & 4,42 & 41,45 & 53,13 & 57,55 & 2,98 & 3,94 & 8,33 \\
\hline CZECH REPUBLIC & 1,34 & 5,14 & 6,28 & 19,98 & 73,30 & 80,13 & 5,41 & 4,06 & 8,33 \\
\hline DENMARK & 1,83 & 1,54 & 2,33 & 62,53 & 96,03 & 95,68 & 9,20 & 8,92 & 10,00 \\
\hline ECUADOR & $-0,96$ & 4,12 & 42,26 & 71,05 & 33,45 & 41,58 & 1,71 & 1,92 & 5,00 \\
\hline EGYPT & 3,88 & 4,62 & 4,12 & 51,06 & 69,05 & 54,78 & 4,68 & 5,12 & 6,67 \\
\hline FINLAND & 1,96 & 3,85 & 1,74 & 58,00 & 98,23 & 96,70 & 9,30 & 8,81 & 10,00 \\
\hline GERMANY & 2,17 & 0,77 & 1,31 & 61,82 & 92,93 & 92,50 & 8,85 & 8,63 & 8,33 \\
\hline HUNGARY & 1,53 & 7,10 & 13,22 & 61,10 & 77,33 & 83,68 & 6,23 & 5,62 & 6,67 \\
\hline ICELAND & 5,68 & 5,37 & 3,59 & 48,08 & 94,75 & 83,83 & 8,69 & 8,41 & 10,00 \\
\hline INDIA & 1,16 & 10,00 & 7,65 & 73,37 & 61,00 & 42,18 & 6,99 & 6,53 & 6,67 \\
\hline INDONISIA & 3,22 & 8,46 & 20,49 & 70,79 & 23,05 & 41,85 & 3,07 & 3,50 & 3,33 \\
\hline IRELAND & 0,58 & 1,54 & 3,60 & 49,55 & 91,65 & 96,38 & 8,03 & 7,58 & 10,00 \\
\hline ISRAEL & 4,62 & 4,10 & 5,87 & 102,79 & 83,20 & 81,35 & 8,83 & 8,62 & 8,33 \\
\hline ITALY & 2,41 & 1,80 & 2,74 & 128,75 & 80,80 & 80,60 & 5,46 & 5,21 & 10,00 \\
\hline JAPAN & 0,44 & 2,31 & $-0,20$ & 122,37 & 89,45 & 77,98 & 6,88 & 5,73 & 8,33 \\
\hline JORDAN & 4,01 & 4,17 & 3,02 & 87,39 & 67,78 & 64,80 & 6,87 & 5,94 & 6,67 \\
\hline KOREA & 4,59 & 8,97 & 4,36 & 12,99 & 77,90 & 70,28 & 5,10 & 5,28 & 6,67 \\
\hline MALAYSIA & 1,64 & 9,23 & 3,03 & 60,93 & 75,08 & 71,08 & 5,24 & 6,52 & 5,00 \\
\hline MARROCOS & 3,09 & 9,21 & 16,21 & 51,58 & 64,68 & 56,18 & 3,64 & 5,30 & 10,00 \\
\hline MEXICO & 3,15 & 8,21 & 2,61 & 74,26 & 48,48 & 73,43 & 3,39 & 4,20 & 3,33 \\
\hline NEW ZEALAND & 4,70 & 1,54 & 2,22 & 46,34 & 97,03 & 96,80 & 9,05 & 8,61 & 10,00 \\
\hline NIGERIA & $-1,65$ & 6,15 & 16,75 & 88,84 & 6,78 & 20,65 & 3,81 & 3,46 & 3,89 \\
\hline NORWAY & 4,14 & 3,59 & 1,97 & 30,65 & 97,83 & 90,75 & 7,98 & 7,67 & 10,00 \\
\hline PAKISTAN & 2,85 & 9,23 & 6,06 & 91,82 & 32,28 & 29,10 & 3,00 & 3,78 & 5,00 \\
\hline PERU & 7,76 & 1,99 & 5,68 & 45,20 & 39,75 & 73,40 & 1,72 & 2,83 & 5,00 \\
\hline PHILIPPENES & 3,91 & 9,23 & 6,52 & 88,67 & 48,63 & 65,30 & 3,87 & 3,66 & 3,33 \\
\hline POLAND & 5,82 & 8,62 & 10,89 & 43,95 & 71,75 & 72,73 & 4,88 & 4,50 & 6,67 \\
\hline RUSSIA & 0,00 & 9,01 & 27,99 & 47,84 & 21,43 & 28,45 & 2,86 & 3,42 & 5,56 \\
\hline SINGAPORE & 1,10 & 4,10 & 0,52 & & 97,78 & 99,73 & 7,05 & 7,85 & 10,00 \\
\hline SLOVAC REPUBLIC & 1,25 & 6,87 & 6,97 & 39,45 & 64,03 & 64,68 & 4,11 & 4,04 & 6,67 \\
\hline SOUTH AFRICA & 5,64 & 9,23 & 6,91 & 43,72 & 64,68 & 62,03 & 7,48 & 7,43 & 3,33 \\
\hline SPAIN & 1,72 & 4,10 & 2,97 & 70,44 & 86,70 & 88,70 & 5,77 & 6,10 & 7,22 \\
\hline SWEDEN & 4,24 & 4,62 & 0,83 & 73,08 & 95,50 & 92,13 & 8,21 & 8,04 & 10,00 \\
\hline SWITZERLAND & 0,96 & 1,54 & 0,76 & & 100,00 & 92,58 & 8,23 & 8,43 & 8,89 \\
\hline THAILAND & 2,32 & 8,46 & 4,03 & 43,03 & 68,10 & 67,38 & 6,07 & 5,13 & 8,33 \\
\hline TURKEY & $(0,85)$ & 7,69 & 66,22 & 57,00 & 60,00 & 66,30 & 4,39 & 4,29 & 6,67 \\
\hline UNITED KINGDOM & 2,88 & 1,54 & 2,61 & 48,45 & 94,68 & 97,85 & 8,69 & 8,60 & 10,00 \\
\hline UNITED STATES & 1,92 & 3,08 & 2,36 & 64,90 & 91,95 & 94,68 & 7,91 & 8,24 & 9,44 \\
\hline URUGUAI & 21,14 & 1,60 & 14,47 & 43,55 & 71,70 & 80,55 & 6,70 & 5,55 & 4,72 \\
\hline VENEZUELA & $-13,99$ & 4,10 & 43,57 & 44,16 & 24,23 & 38,15 & 0,83 & 1,69 & 4,44 \\
\hline
\end{tabular}

Sources: IMF's IFS. World Bank, Kaufmann et al. (2004), Fraser Institute, Gwartney and Lawson (2004) and author's calculations. 